\title{
26. FOSSIL POLYMETALLIC CONCRETIONS FROM DEEP SEA DRILLING PROJECT LEG 81: MINERALOGICAL, GEOCHEMICAL, AND STATISTICAL STUDIES ${ }^{1}$
}

\author{
C. Jehanno, Centre des Faibles Radioactivités, CEA-CNRS \\ and
}

E. Lallier-Vergès, C. Bonnot-Courtois, A. Desprairies, J. Bijon, and M. Rivière,

Laboratoire de Géochimie des Roches Sédimentaires, Université de Paris-Sud ${ }^{2}$

\section{INTRODUCTION}

Three types of concretions were recovered during Leg 81 from Holes 552A, 553A, and 554A (Table 1), located on the west margin of the Rockall Plateau (Fig. 1). In the sedimentary section, these concretions are located at the level of major unconformities, in condensed sequences representing a period from early Eocene to Miocene. This study is a detailed mineralogical and geochemical investigation that permits comparison among the three holes and between the fossil Leg 81 concretions and recent polymetallic nodules found on the ocean floor.

\section{ANALYTICAL PROCEDURE}

Several techniques were used for the mineralogical and geochemical data:

1. A scanning electron microscope (Camebax) with an X-ray dispersive spectrometer (Edax) was used for morphological examination, mineral analysis by point, global analyses of samples for areas of several square millimeters, and also for nannofossil specification. The quantitative analysis is conducted with a nonautomatic ZAF program, using standard minerals. The sample porosity does not allow for correction of $100 \%$ of the oxides, weight deficit for the water content; we have normalized all analyses to $80 \%$. This approximation is justified by the results of the chemical analyses obtained on the same whole samples (hydroxides, clay minerals, etc.).

The relative errors are (1) less than $5 \%$ for elements whose concentrations are $>10 \%$, (2) $10 \%$ for elements whose concentrations are between 5 and $10 \%$, and (3) $\sim 20 \%$ for elements whose concentrations are $<5 \%$.

The detection limit is $1000 \mathrm{ppm}(0.1 \%)$. The data reported in the tables are typical analyses of a facies or a group of minerals. Several typical analyses are reported if an important variation appears.

2. X-ray mineralogy determinations were performed on bulk samples or clay fractions $(<2 \mu \mathrm{m})$ with a Philips diffractometer system equipped with a graphite crystal monochromator ( $\mathrm{CuK}_{\alpha}$ radiation).

3. Instrumental neutron activation analysis was used for determination of trace elements in selected samples. The rare earth elements (REE) were measured by chemical neutron activation; details of the chemical separation after irradiation are described in Courtois and Jaffrezic-Renault (1977). The countings were made on high-resolution $\mathrm{GeLi}$ detectors. The analytical error for each measurement is about $10 \%$.

4. A large number $(\simeq 130)$ of microprobe analyses were conducted on Samples from Holes 552 and 553, allowing statistical study.

\footnotetext{
${ }^{1}$ Roberts, D. G., Schnitker, D., et al., Init. Repts. DSDP, 81: Washington (U.S. Govt. Printing Office).

2 Address: (Jehanno) Centre des Faibles Radioactivités CEA-CNRS, 91190, Gif-surYvette, France; (Lallier-Verges, Bonnot-Courtois, Desprairies, Bijon, Riviere) Laboratoire de Géochimie des Roches Sedimentaires, Université de Paris-Sud, 91405, Orsay, France.
}

Table 1. Location of concretions from Leg 81 DSDP.

\begin{tabular}{ccccc}
\hline Hole & Longitude & Latitude & $\begin{array}{c}\text { Water depth } \\
(\mathrm{m})\end{array}$ & $\begin{array}{c}\text { Depth of concretion } \\
\text { below seafloor } \\
(\mathrm{m})\end{array}$ \\
\hline $552 \mathrm{~A}$ & $23^{\circ} 13.39^{\prime} \mathrm{W}$ & $56^{\circ} 02.56^{\prime} \mathrm{N}$ & 2311 & 174 \\
$553 \mathrm{~A}$ & $23^{\circ} 20.61^{\prime} \mathrm{W}$ & $56^{\circ} 05.32^{\prime} \mathrm{N}$ & 2339 & 235 \\
$554 \mathrm{~A}$ & $23^{\circ} 31.69^{\prime} \mathrm{W}$ & $56^{\circ} 17.41^{\prime} \mathrm{N}$ & 2584 & 119 \\
\hline
\end{tabular}

\section{DESCRIPTIONS AND ANALYSES}

\section{Hole 552A}

Hole 552 was drilled in $2315 \mathrm{~m}$ of seawater. At $174 \mathrm{~m}$ below the water/sediment interface, a $1.50-\mathrm{m}$ condensed sequence representing the late Eocene, Oligocene, and middle Miocene was recovered (Fig. 2). In Sample 552A$37-1,19-23 \mathrm{~cm}$ of this sequence, a Fe-Mn nodule is interstratified in a sedimentary section for which the observations made on the Glomar Challenger reveal a disordered stratigraphy from Zone NP15 to NP24 (Plate 1). The surface of the nodule is covered with carbonate ooze, smectites, Mn oxides, and zeolites (Plate 2, Fig. 1). The nannofossil assemblage contains Ismolithus recurvus, Discoaster barbadiensis, D. saipanensis, Reticulofenestra umbilica, and several Chiasmolithus (Plate 2, Figs. 2-6). This assemblage corresponds to Zone NP1920 , which seems to be the period of nodule burial. Indeed, nodules are growing at the sediment water/interface, as seen with radioactivity measurements $(\mathrm{Ku}$ and Broecker, 1969) but cease growing when they are buried (Somayajulu et al., 1971). In the nodule from Hole $552 \mathrm{~A}$ we found no excess of ${ }^{230} \mathrm{Th}$, since it is a fossil nodule (Reyss, pers. comm.).

The nodule has an ellipsoidal shape, the larger section having axes of 7.1 and $4.4 \mathrm{~cm}$. The $\mathrm{Fe}-\mathrm{Mn}$ oxides are $8 \mathrm{~mm}$ thick and encrust an indurated ellipsoidal nucleus.

\section{The Nucleus}

The nucleus is almost completely formed by indurated clay and by rare diatoms and phosphatic debris. Cracks are filled with zeolites and manganese; some onionlike dendritic structures of Mn-oxides penetrate the clays (Plate 3, Fig. 2). Many cavities with angular sides exist; they are rarely filled by minerals but always covered with authigenic clays (Plate 3, Fig. 1-4). These cavities corre- 


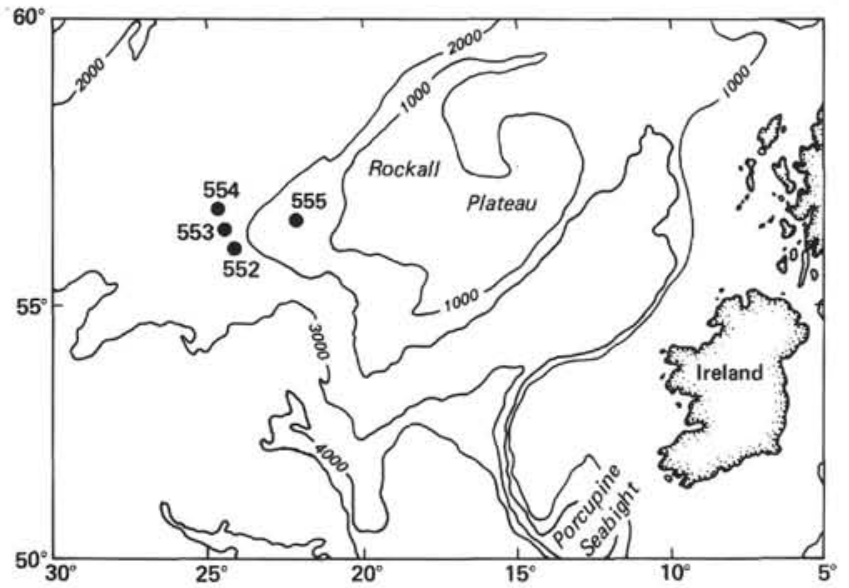

Figure 1. Location of Leg 81 sites.

spond to the dissolution of volcanogenic material. Some glasses are still present, but the polishing did not preserve them sufficiently to allow analyses. The chemical analyses (Table 2) show that the average $\mathrm{TiO}_{2}$ content is $3 \%$ and reaches $10 \%$ for some brown areas where iron is also enriched. Clays have an X-ray powder pattern of dioctahedral iron smectites (060 peak 1,505 $\AA$; Desprairies, 1983) and are well crystallized (Fig. 3A). The chemical compositions and structural formulas of these minerals are nearly iron beidellites, with high tetrahedral charge, and $\mathrm{Fe}-\mathrm{Al}$ substitution below or equal to 1 (Weaver and Pollard, 1973). The cavities are covered with more $\mathrm{Mg}$ and slightly more siliceous beidellites than the average composition (Table 2 , columns $\mathrm{d}_{1}, \mathrm{~d}_{2}$ ), and the $\mathrm{TiO}_{2}$ content is very low.

The chondritic normalized REE distribution is light REE (LREE) enriched $(\mathrm{La} / \mathrm{Yb}=19.6)$. A positive $\mathrm{Ce}$ anomaly appears and is quite pronounced $\left(\mathrm{Ce} / \mathrm{Ce}^{*}=\right.$ 5.6; $\mathrm{Ce}$ is the measured concentration and $\mathrm{Ce}^{*}$ is the interpolated value between $\mathrm{La}$ and $\mathrm{Nd}$ as if the Ce shows no anomaly). Apart from Ce, the absolute REE concentrations are still low for clay material (Piper, 1974a,b) (Table 3, Fig. 4).

\section{Contact between Nucleus and $\mathrm{Fe}-\mathrm{Mn}$ Concretion Crustal Zone}

This zone contains biogenous debris that underlines an important organic activity at the beginning of the




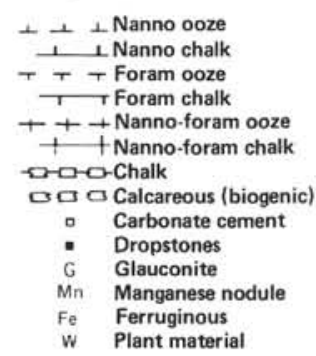

Figure 2. Stratigraphy and condensed sequences: Sites 552, 553, 554. 
Table 2. Nucleus of nodule from Hole 552. Chemical compositions and structural formulas of smectite calculated on 11 oxygens.

\begin{tabular}{|c|c|c|c|c|c|c|c|c|}
\hline & $a_{1}$ & $a_{2}$ & $a_{3}$ & b & $c_{1}$ & $c_{2}$ & $\mathrm{~d}_{1}$ & $\mathrm{~d}_{2}$ \\
\hline $\mathrm{Na}_{2} \mathrm{O}$ & 1.04 & 2.32 & N.D. & N.D. & 2.03 & 1.96 & 2.78 & 0.81 \\
\hline $\mathrm{MgO}$ & 2.80 & 3.28 & 3.12 & 0.92 & 2.73 & 3.14 & 5.94 & 4.30 \\
\hline $\mathrm{Al}_{2} \mathrm{O}_{3}$ & 14.20 & 12.0 & 11.8 & 8.72 & 12.67 & 12.01 & 10.17 & 9 \\
\hline $\mathrm{SiO}_{2}$ & 43.41 & 43.7 & 42.5 & 34.32 & 44.13 & 46.02 & 47.2 & 47.9 \\
\hline $\mathrm{K}_{2} \mathrm{O}$ & 2.04 & 1.84 & 2.0 & 1.28 & 1.95 & 1.55 & 1.97 & 2.33 \\
\hline $\mathrm{CaO}$ & 1.01 & 0.84 & 0.70 & 1.20 & 1.39 & 1.06 & 0.29 & 0.39 \\
\hline $\mathrm{TiO}_{2}$ & 2.32 & 3.52 & 3.04 & 9.92 & 3.24 & 3.19 & 1.01 & 1.28 \\
\hline MnŌ & 0.11 & 0.12 & 0.24 & 0.64 & 0.11 & & & \\
\hline $\mathrm{Fe}_{2} \mathrm{O}_{3}$ & 13.16 & 12.40 & 16.51 & 23.12 & 11.62 & 10.95 & 10.59 & 13.80 \\
\hline \multicolumn{9}{|c|}{ Tetrahedral } \\
\hline $\mathrm{Si}$ & 3.56 & 3.64 & 3.56 & & & & 3.78 & 3.86 \\
\hline $\mathrm{Al}$ & 0.44 & 0.36 & 0.44 & & & & 0.22 & 0.14 \\
\hline \multicolumn{9}{|c|}{ Octahedral } \\
\hline $\mathrm{Al}_{3}$ & 0.93 & 0.82 & 0.73 & & & & 0.74 & 0.72 \\
\hline $\mathrm{Fe}^{3+}$ & 0.81 & 0.78 & 1.04 & & & & 0.63 & 0.84 \\
\hline $\mathrm{Mg}$ & 0.33 & 0.41 & 0.34 & & & & 0.71 & 0.52 \\
\hline \multicolumn{9}{|c|}{ Interlayer } \\
\hline $\mathrm{Na}$ & 0.16 & 0.37 & - & & & & 0.43 & 0.13 \\
\hline K & 0.21 & 0.19 & 0.21 & & & & 0.20 & 0.24 \\
\hline $\mathrm{Ca}$ & 0.09 & 0.08 & 0.06 & & & & 0.03 & 0.03 \\
\hline $\mathrm{Mg}$ & - & & 0.05 & & & & & \\
\hline
\end{tabular}

Note: Dash indicates no data. a, b, SEM/EDS, polished sections; b, Fe-Ti enriched zone; c, direct-current plasma, atomic emission spectroscopy analysis; d, phyllites.

manganiferous deposit (Plate 3, Figs. 5, 6). Phillipsite occurs in the cavities and $\mathrm{Fe}$ and $\mathrm{Ti}$ concentrations are higher than those found in the nucleus (Table 4, column $\mathrm{C}_{1}$ ).

\section{The Fe-Mn Zone}

The crustal zone is constituted by typical " $\delta \mathrm{MnO}_{2}$ " botryoids (Plate 4, Fig. 1) with three more dense and darker groups of laminations that correspond to Mn enrichment (Plate 4, Fig. 2). The Fe/Mn ratio of 2.2 in the major phase decreases to 0.4 in the Mn laminations. Some lenticular Mn-depleted zones are switched in the structure (Table 4, column $b_{4}$ ).

$\mathrm{X}$-ray analysis reveals very rare quartz, feldspars, and amorphous silica, and a small amount of phillipsite. With a weak peak at $9.8 \AA$ of todorokite, the typical $\delta$ $\mathrm{MnO}_{2}$ reflections exist around $2.44,2.25$, and $1.41 \AA$. A weak 060 reflection of the smectites appears at $1.51 \AA$ (Fig. 5A). A transverse analysis reveals nonsystematic variations for major elements associated with the major
A

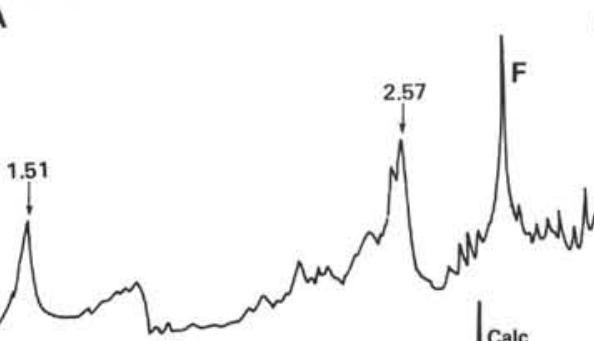<smiles>C#CCCCCCCCCCCCCCCCCC</smiles>

B

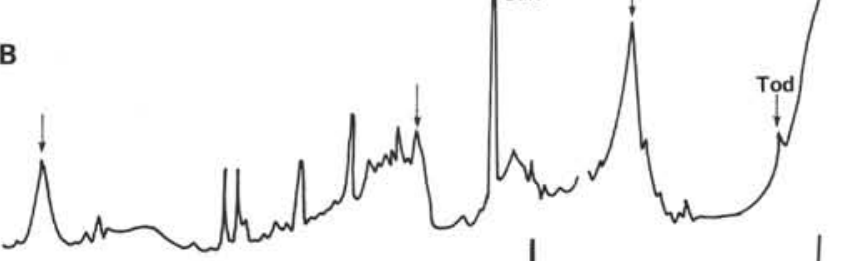



Figure 3. X-ray diffraction diagrams of smectite samples. A. Nodule from Hole 552A, nucleus. B. Nodule from Hole 552, external zone. C. Nodule from Hole 553, crustal zone. D. Nodule from Hole $554 \mathrm{~A}$, external green clay.

Fe-rich phase, except for Ti which is enriched near the nucleus and decreases rapidly in the first few millimeters (Table 5, Fig. 6).

Transition elements $(\mathrm{Co}+\mathrm{Cu}+\mathrm{Ni})$ have contents $<0.5 \%$ in the dominant phase but exceed $3 \%$ in some Mn-enriched zones, where Co reaches $1 \%$. The chondritic normalized REE pattern is LREE enriched (La/ $\mathrm{Yb}=15.1)$ and shows a strong positive Ce anomaly $\left(\mathrm{Ce} / \mathrm{Ce}^{*}=7\right)$. Absolute REE concentrations are high (Table 3, Fig. 4).

Table 3. REE and transition element concentrations (ppm).

\begin{tabular}{lcccccccccccrrr}
\hline \multicolumn{1}{c}{ Sample } & $\mathrm{La}$ & $\mathrm{Ce}$ & $\mathrm{Nd}$ & $\mathrm{Sm}$ & $\mathrm{Eu}$ & $\mathrm{Tb}$ & $\mathrm{Yb}$ & $\mathrm{Lu}$ & $\mathrm{Total}$ & $\mathrm{La} / \mathrm{Yb}$ & $\mathrm{Ce} / \mathrm{Ce} *$ & $\mathrm{Cu}$ & $\mathrm{Co}$ & $\mathrm{Ni}$ \\
\hline Hole 552 nucleus & 10.0 & 109 & 8.8 & 2.4 & 0.65 & 0.27 & 0.50 & 0.08 & 132 & 19.6 & 5.5 & 238 & 78 & 280 \\
Hole 552 cortex & 88.0 & 1231 & 86 & 20.0 & 4.9 & 3.6 & 5.8 & 0.9 & 1440 & 15.1 & 7 & 970 & 2374 & 2346 \\
Hole 553 cortex & 6.8 & 30.0 & 8.3 & 1.9 & 0.53 & 0.25 & 0.60 & 0.10 & 48 & 11.3 & 2.1 & & \\
Hole 553 brown clays & 9.0 & 33.5 & 8.5 & 1.5 & 0.38 & 0.2 & 0.5 & 0.09 & 54 & 18.0 & 1.9 & 224 & 0 & 310 \\
Hole 553 green clays & 9.5 & 15.5 & 7.5 & 1.4 & 0.35 & 0.12 & 0.35 & 0.06 & 35 & 27.2 & 1 & 189 & 0 & 208 \\
Nontr. Galapagos (a) & 0.3 & 0.42 & 0.46 & 0.08 & 0.02 & 0.02 & 0.08 & 0.015 & 2 & 0.2 & 0.87 & 61 & 15 & 34 \\
$\begin{array}{l}\text { Fe oxide, Romanche } \\
\quad \text { Trench (b) }\end{array}$ & 260 & 1290 & 306 & 61 & 11.4 & 6 & 12.5 & 1.7 & 1949 & 20.8 & 2.18 & 1200 & 500 & 770 \\
\hline
\end{tabular}

Note: a, from Hoffert et al. (1980); b, from Bonté (1981). 


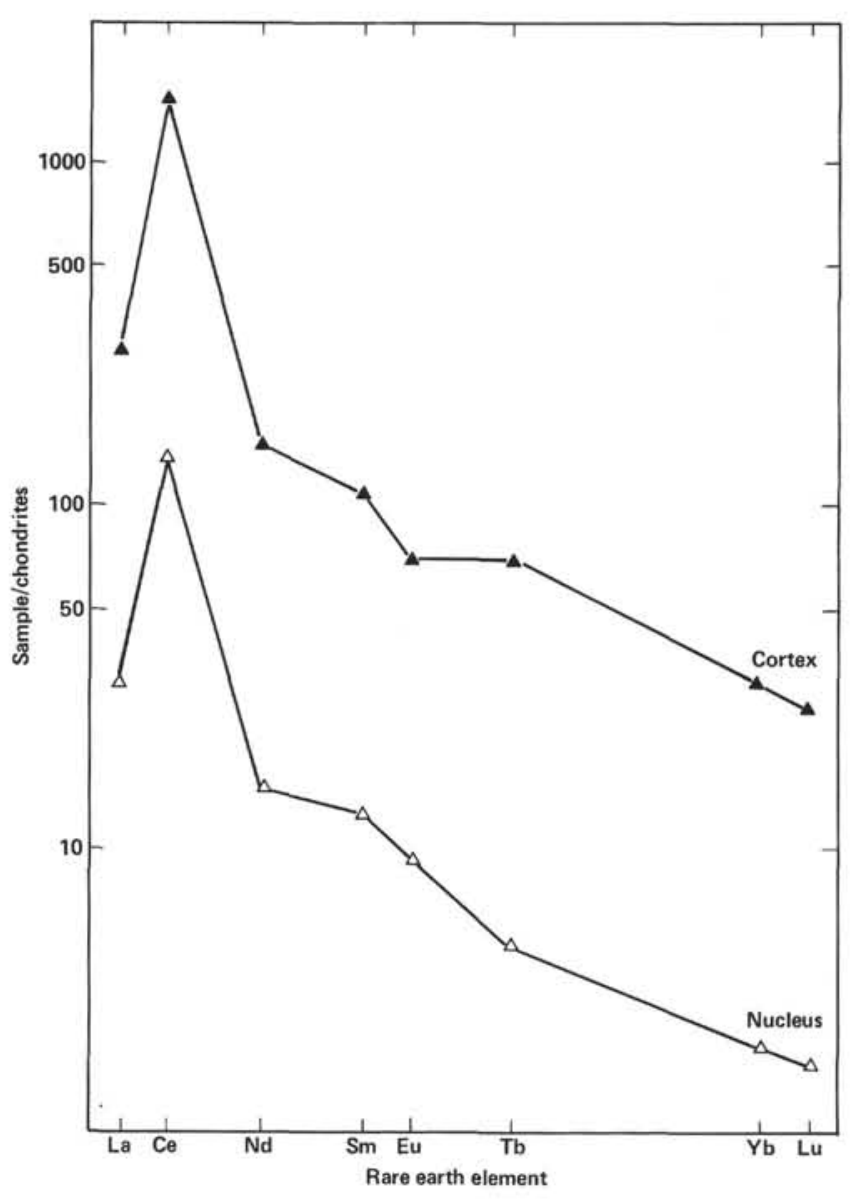

Figure 4. REE abundance patterns of nodule from Hole 552A, nucleus and cortex (or crustal zone).

\section{Cracks and the External Zone}

In the upper part of the crustal zone (Plate 4, Fig. 3a), two types of fissuration have been recognized: the first one, concentric, is filled by green clays; the second one, sometimes concentric but also radial, is chiefly filled by a white powdery sediment with much calcareous debris. The two types of fillings are composed by
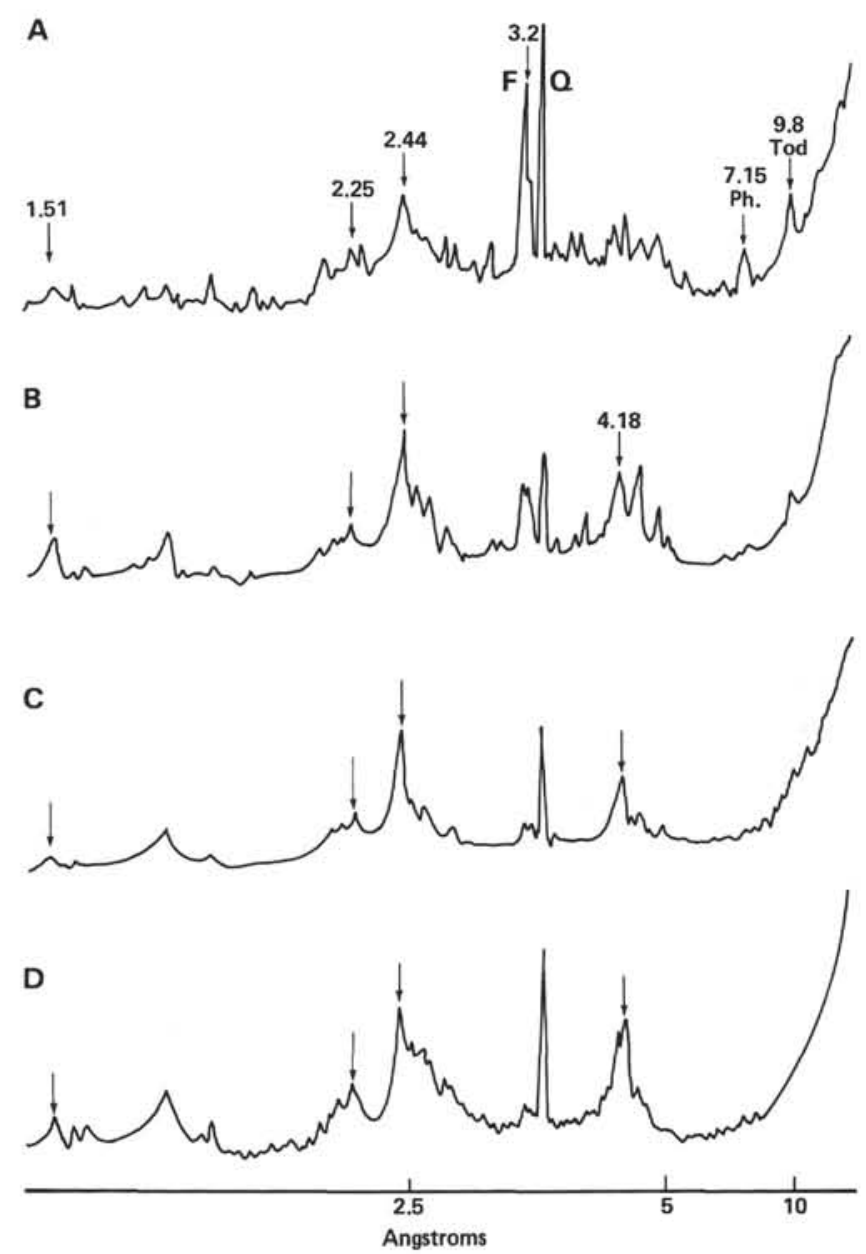

Figure 5. X-ray diffraction diagrams of " $\mathrm{SMnO}_{2}$ " samples. A. Nodule from Hole 552A, crustal zone. B. Nodule from Hole 554A, crustal zone. C. Atlantic Fe-rich nodule from Bermuda zone. D. Mn-depleted Fe oxides from Romancha Trench.

Mn deposits with low Fe content associated with important phillipsite crystallizations (Plate 4, Figs. 4, 5).

The external zone contains green clays, associated with Mn oxides and phillipsites in a carbonate deposit (Plate 5, Fig. 1). A thin outer Mn-oxide layer partially exists.

Table 4. Chemical composition of crustal zone of nodule from Hole 552A.

\begin{tabular}{|c|c|c|c|c|c|c|c|c|c|c|c|c|c|c|}
\hline & \multirow{2}{*}{\multicolumn{2}{|c|}{ Total analysis }} & \multicolumn{7}{|c|}{$\mathrm{Fe} / \mathrm{Mn}>1$} & \multirow{2}{*}{\multicolumn{5}{|c|}{$\mathrm{Fe} / \mathrm{Mn}<1$}} \\
\hline & & & \multicolumn{4}{|c|}{ Upper zone } & \multicolumn{3}{|c|}{ Bottom zone } & & & & & \\
\hline & $a_{1}$ & $a_{2}$ & $\mathrm{~b}_{1}$ & $b_{2}$ & $b_{3}$ & $\mathrm{~b}_{4}$ & $c_{1}$ & $c_{2}$ & $c_{3}$ & $d_{1}$ & $d_{2}$ & $d_{3}$ & $d_{4}$ & e \\
\hline $\mathrm{Na}_{2}$ & 2.72 & 2.64 & 2.55 & 2.70 & 2.32 & 2.24 & 1.65 & 2.04 & 2.41 & 2.09 & 2.13 & 2.38 & 1.99 & 2.29 \\
\hline $\mathrm{MgO}$ & 2.24 & 2.16 & 1.77 & 1.85 & 3.70 & 3.25 & 2.17 & 1.69 & 1.53 & 6.06 & 6.85 & 5.52 & 2.93 & 6.47 \\
\hline $\mathrm{Al}_{2} \mathrm{O}_{3}$ & 5.04 & 5.04 & 8.70 & 5.62 & 4.33 & 10.39 & 5.21 & 3.97 & 4.16 & 5.23 & 6.65 & 4.17 & 4.00 & 6.10 \\
\hline $\mathrm{SiO}_{2}$ & 30.88 & 29.36 & 23.29 & 28.77 & 20.27 & 32.4 & 25.12 & 31.20 & 37.95 & 14.76 & 11.74 & 16.81 & 27.13 & 22.42 \\
\hline $\mathrm{K}_{2} \mathrm{O}$ & 0.88 & 0.72 & 0.32 & 0.55 & 0.56 & 1.61 & 0.41 & 0.22 & 0.32 & 0.25 & 0.4 & 0.36 & 0.36 & 0.69 \\
\hline $\mathrm{CaO}$ & 1.04 & 0.96 & 1.35 & 1.26 & 2.71 & 0.70 & 2.53 & 1.70 & 1.31 & 1.18 & 1.29 & 0.87 & 1.34 & 2.39 \\
\hline $\mathrm{TiO}_{2}$ & 1.12 & 1.22 & 2.06 & 1.53 & 1.50 & 0.61 & 6.18 & 1.41 & 0.92 & 1.25 & 0.99 & 1.6 & 1.9 & $<0.1$ \\
\hline $\mathrm{MnO}$ & 9.68 & 11.04 & 11.61 & 10.26 & 16.45 & 1.83 & 11.82 & 9.53 & 7.26 & 30.90 & 36.30 & 27.2 & 28.14 & 29.2 \\
\hline $\mathrm{Fe}_{2} \mathrm{O}_{3}$ & 26.30 & 25.92 & 27.78 & 26.86 & 26.76 & 26.69 & 24.30 & 27.57 & 23.77 & 14.91 & 9.6 & 18.73 & 10.06 & 7.08 \\
\hline $\mathrm{CoO}$ & 0.23 & 0.21 & 0.16 & 0.16 & 0.57 & 0.17 & N.D. & N.D. & 0.1 & 0.96 & 1.09 & 0.85 & 0.81 & 0.29 \\
\hline $\mathrm{NiO}$ & 0.23 & 0.21 & $<0.1$ & 0.21 & 0.64 & 0.16 & 0.15 & 0.1 & 0.15 & 2.16 & 2.38 & 1.39 & 0.78 & 2.33 \\
\hline $\mathrm{CuO}$ & 0.12 & 0.11 & $<0.1$ & 0.1 & 0.14 & $<0.1$ & $<0.1$ & 0.13 & $<0.1$ & 0.22 & 0.57 & 0.12 & 0.16 & 0.7 \\
\hline
\end{tabular}

Note: N.D. indicates no data. a, Direct-current plasma, atomic emission spectroscopy analysis; b, c, d, e: SEM/EDS, polished sections; $b_{4}, M n$-depleted zone; $c_{1}$, Core-crustal zone contact; $d$, todorokite laminations. 
Table 5. Decrease in concentration of $\mathrm{Ti}$ with distance nucleus of nodule from Hole 552A.

\begin{tabular}{lrrrrrrrr}
\hline & \multicolumn{8}{c}{ Distance from nucleus (mm) } \\
& \multicolumn{1}{c}{0} & \multicolumn{1}{c}{0.5} & \multicolumn{1}{c}{0.8} & \multicolumn{1}{c}{2} & 3.25 & \multicolumn{1}{c}{4.5} & 5.75 & \multicolumn{1}{c}{7} \\
\hline $\mathrm{Na}_{2} \mathrm{O}$ & 1.67 & 3.25 & 2.90 & 2.48 & 2.16 & 2.44 & 2.20 & 2.32 \\
$\mathrm{MgO}$ & 2.18 & 2.68 & 2.71 & 2.53 & 2.53 & 2.48 & 2.66 & 4.67 \\
$\mathrm{Al}_{2} \mathrm{O}_{3}$ & 5.24 & 11.27 & 7.41 & 6.96 & 8.72 & 7.82 & 8.43 & 6.71 \\
$\mathrm{SiO}_{2}$ & 25.29 & 28.57 & 28.41 & 29.75 & 29.7 & 30.93 & 30.13 & 33.93 \\
$\mathrm{~K}_{2} \mathrm{O}$ & 0.41 & 0.87 & 0.75 & 0.69 & 0.70 & 0.58 & 0.68 & 1.26 \\
$\mathrm{CaO}$ & 2.55 & 1.28 & 1.38 & 1.20 & 1.27 & 1.21 & 0.42 & 0.69 \\
$\mathrm{TiO}_{2}$ & 6.22 & 2.23 & 1.65 & 1.42 & 0.80 & 0.92 & 1.22 & 0.67 \\
$\mathrm{MnO}$ & 11.92 & 9.75 & 10.98 & 10.53 & 8.77 & 8.36 & 9.92 & 11.31 \\
$\mathrm{Fe}_{2} \mathrm{O}_{3}$ & 24.49 & 19.93 & 23.67 & 23.86 & 25.10 & 25.17 & 23.23 & 17.85 \\
$\mathrm{NiO}$ & - & 0.12 & 0.1 & 0.57 & 0.22 & 0.12 & 0.31 & 0.58 \\
& & & & & & & &
\end{tabular}

Note: Dash indicates no data.

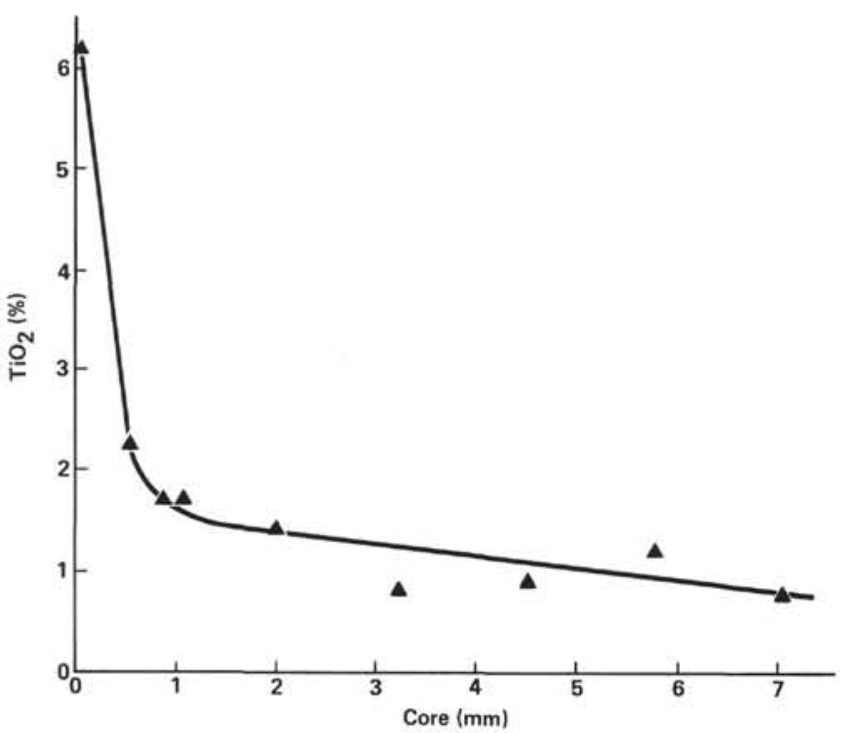

Figure 6. $\mathrm{TiO}_{2}$ decrease with distance from nucleus of nodule from Hole 552A.

The association between clays, Mn oxides, and phillipsite exists in the two types of fissuration and in the external zone. In all three cases, carbonate is abundant. It is almost completely replaced by green clays in the first cracks (Plate 5, Fig. 2) but only partly in the white deposits and the external zone (Plate 5, Figs. 3, 4). These clays are dioctahedral smectites (Fig. 3b). The 100\% deficit is high $(35 \%)$ for the white clays and low $(15 \%)$ for the green clays that have more dense texture. According to the iron content, the white clays are similar to iron beidellites (octahedral-Fe $\leq 1$, Table 6). However, these two types of smectite have low $\mathrm{Al}$ content $(\mathrm{Mg} / \mathrm{Al}$ ratio $\simeq 1$ ) and consequently a low tetrahedral charge. This fact is in agreement with the montmorillonite family rather than the beidellite-nontronite family (Brindley and Brown, 1980). Therefore, the fissural white smectites are different from the volcanogenic smectites of the nucleus.

Hydrated Mn oxides (todorokite, Fig. 3B) occur either with a massive structure that contains a very low concentration in transition elements, or as laminated "micronodules" (Plate 5, Figs. 1-4, Table 7). $\mathrm{BaO}$, which
Table 6. Nodule from Hole 552A. Chemical composition of clays filling the cracks and structural formulas calculated on 11 oxygens.

\begin{tabular}{|c|c|c|c|c|c|c|c|c|}
\hline & \multicolumn{4}{|c|}{ White clay } & \multicolumn{4}{|c|}{ Green clay } \\
\hline & $a_{1}$ & $b_{1}$ & $b_{2}$ & c & $a_{2}$ & $a_{3}$ & $b_{3}$ & $b_{4}$ \\
\hline $\mathrm{Na}_{2} \mathrm{O}$ & - & 0.27 & - & - & 1.07 & 0.24 & 0.8 & - \\
\hline $\mathrm{MgO}$ & 5.65 & $6: 45$ & 5.13 & 4.37 & 3.57 & 3.66 & 3.05 & 2.98 \\
\hline $\mathrm{Al}_{2} \mathrm{O}_{3}$ & 6.09 & 4.26 & 5.78 & 7.05 & 6.27 & 3.59 & 3.06 & 3.52 \\
\hline $\mathrm{SiO}_{2}$ & 50.09 & 47.35 & 48.64 & 40.9 & 46.85 & 47.47 & 46.73 & 46.55 \\
\hline $\mathrm{K}_{2} \mathrm{O}$ & 1.83 & 2.26 & 1.86 & 2.02 & 1.86 & 2.42 & 2.06 & 2.41 \\
\hline $\mathrm{CaO}$ & 1.73 & 1.05 & 2.96 & 1.2 & 0.94 & 0.69 & 0.78 & 1.05 \\
\hline $\mathrm{TiO}_{2}$ & - & - & 0.12 & 0.35 & - & - & - & - \\
\hline MnO & 0.58 & 0.8 & 0.67 & 0.58 & 0.19 & 0.2 & 0.28 & 0.32 \\
\hline $\mathrm{Fe}_{2} \mathrm{O}_{3}$ & 13.86 & 17.5 & 14.81 & 23.49 & 19.25 & 21.72 & 23.17 & 23.16 \\
\hline \multicolumn{9}{|c|}{ Tetrahedral } \\
\hline $\mathrm{Si}$ & 3.99 & 3.88 & 3.92 & & 3.82 & 3.90 & 3.88 & 3.87 \\
\hline Al & 0.01 & 0.12 & 0.08 & & 0.18 & 0.10 & 0.12 & 0.13 \\
\hline \multicolumn{9}{|c|}{ Octahedral } \\
\hline $\mathrm{Al}$ & 0.56 & 0.29 & 0.47 & & 0.42 & 0.25 & 0.18 & 0. \\
\hline $\mathrm{Fe}^{3+}$ & 0.83 & 1.07 & 0.91 & & 1.18 & 1.34 & 1.45 & \\
\hline $\mathrm{Mg}$ & 0.67 & 0.79 & 0.62 & & 0.43 & 0.45 & 0.37 & 0.37 \\
\hline \multicolumn{9}{|c|}{ Interlayer } \\
\hline $\mathrm{Na}$ & - & 0.04 & - & & 0.17 & 0.04 & 0.13 & - \\
\hline $\mathrm{K}$ & 0.18 & 0.24 & 0.19 & & 0.19 & 0.26 & 0.22 & 0. \\
\hline $\mathrm{Ca}$ & 0.15 & 0.09 & 0.25 & & 0.08 & 0.06 & 0.07 & 0.09 \\
\hline $\mathrm{Mg}$ & - & & & & & & & \\
\hline
\end{tabular}

Note: Dash indicates no data. a, outside foraminifer; $b$, inside foraminifer; c, brown zone.

Table 7. Micronodule chemical compositions, Hole 552A.

\begin{tabular}{|c|c|c|c|c|c|c|c|c|}
\hline \multirow[b]{2}{*}{$\mathrm{Na}_{2} \mathrm{O}$} & \multicolumn{2}{|c|}{ a } & \multicolumn{4}{|c|}{ b } & \multirow{2}{*}{$\begin{array}{c}\mathrm{c} \\
3.27\end{array}$} & \multirow{2}{*}{$\frac{d}{1.3}$} \\
\hline & 1.76 & 2.73 & 1.48 & 1.93 & N.D. & 1.62 & & \\
\hline $\mathrm{MgO}^{2}$ & 6.71 & 7.83 & 4.46 & 4.11 & 9.06 & 2.99 & 1.11 & 1.30 \\
\hline $\mathrm{Al}_{2} \mathrm{O}_{3}$ & 7.38 & 5.54 & 2.4 & 2.30 & 5.14 & 1.29 & 1.02 & 1.92 \\
\hline $\mathrm{SiO}_{2}$ & 18.73 & 7.98 & 2.15 & 6.30 & 1.58 & 1.69 & 0.82 & 0.77 \\
\hline $\mathrm{K}_{2} \mathrm{O}^{-}$ & 0.64 & 0.64 & 0.8 & 0.97 & 0.25 & 0.97 & 1.35 & 2.6 \\
\hline $\mathrm{CaO}$ & 0.74 & 0.96 & 0.96 & 5.33 & 1.53 & 1.06 & 4.60 & \\
\hline $\mathrm{TiO}_{2}$ & 1.34 & 0.95 & & & & & & \\
\hline MnO & 35.23 & 46.4 & 58.47 & 52 & 49.15 & 63.87 & 64.81 & 60.54 \\
\hline $\mathrm{Fe}_{2} \mathrm{O}_{3}$ & 4.2 & 3.58 & 4.58 & 4.33 & 5.1 & 3.70 & 2.77 & 2.53 \\
\hline $\mathrm{CoO}$ & 0.9 & 0.88 & 0.94 & 0.5 & 1.35 & 0.16 & & \\
\hline $\mathrm{NiO}$ & 2.05 & 2.19 & 2.67 & 1.1 & 4.9 & 0.24 & 0.1 & \\
\hline $\mathrm{CuO}$ & 0.36 & 0.3 & 0.50 & 0.4 & 1.36 & 0.34 & & \\
\hline $\mathrm{BaO}$ & & & 1.36 & 0.77 & 0.44 & 1.95 & & 8.97 \\
\hline
\end{tabular}

Note: a, micronodules from the nucleus; $b$, onionlike micronodules; $c$, massive structures; $\mathrm{d}$, psilomelane.

is always present, reaches $9 \%$ in foraminiferal fillings of the external zone. The zeolite is a Na-K phillipsite with an average $\mathrm{Si} / \mathrm{Al}$ ratio of 2.9 .

\section{Hole 553}

At $2339 \mathrm{~m}$ depth in Hole 553, $200 \mathrm{~m}$ below the water/ sediment interface, a nearly $50-\mathrm{m}$ condensed sequence representing an interval between the middle Eocene to the late Miocene with several unconformities was recovered (Fig. 2). In Sample 553-9-6, 4-6 cm a round nodule of $27-\mathrm{mm}$ diameter is located at the Zone NP25 stratigraphic level, which marks a hiatus between the Oligocene and the middle Eocene. This is a clay-iron oxide concretion surrounding a 3-mm diameter nucleus (Plate 6, Fig. 1).

The nucleus is composed of biogenic sediment replaced by phillipsite and green clays indurated by silica 
(Plate 6, Fig. 2). The crustal zone has a botryoidal structure similar to the typical nodules, but without $\mathrm{Mn}$ (Plate 6, Figs. 3, 4). It is formed by brown clays sometimes enriched by Fe hydroxides (up to $35 \% \mathrm{Fe}_{2} \mathrm{O}_{3}$, Table 8). X-ray data show the 060 smectite reflection situated at $1.510 \AA$, which corresponds to Fe dioctahedral smectites (Fig. 3C). Green clays are interbedded within the structure (Plate 6, Fig. 4), fill the cracks, and also cover some parts of the nodule and indurate the surrounding sediment. The chemical compositions are reported in Table 8 . The iron contents are lower in the green clays than in the brown clays. Al contents remain low and are of the same order as in Site 552 nodule cracks. The $\mathrm{Mg} / \mathrm{Al}$ ratio varies from 0.6 in the green clay of the crustal zone to 4 for green clays found in the external zone or in the surrounding sediment (Plate 6, Figs. 5, 6.). Some $\mathrm{Fe}$ smectites are very depleted in $\mathrm{Al}_{2} \mathrm{O}_{3}$ (Table 8, columns f, g), and it becomes difficult to calculate the structural formula of these minerals without the input of Si tetrahedral excess of charge, which is theoretically not acceptable (excess of silica comes from amorphous material not identified by X-ray). Nevertheless, the composition of these smectites is very close to that of Si-Fe "nontronites" found in oceanic hydrothermal deposits (Corliss et al., 1978; Hoffert et al., 1980), but this does not mean that these minerals have the same origin.

Phillipsites, which occur in the nucleus and in the crustal zone, are $\mathrm{Na} / \mathrm{K}$ phillipsite and have a $\mathrm{Si} / \mathrm{Al}$ ratio of 2.9. REE analyses have been conducted on the whole crust and on separated brown and green clays. The patterns of the three phases are LREE enriched (Fig. 7) $(\mathrm{La} / \mathrm{Yb}=16)$. A weak positive $\mathrm{Ce}$ anomaly appears $\left(\mathrm{Ce} / \mathrm{Ce}^{*}=2\right.$, Table 3$)$ in the whole crust, mainly formed of brown clays, and also in the brown clays themselves.

Table 8. Chemical compositions of different facies and structural formulas of smectites calculated on 11 oxygens, Hole $553 \mathrm{~A}$ nodule.

\begin{tabular}{|c|c|c|c|c|c|c|c|c|}
\hline & a & b & $c_{1}$ & $c_{2}$ & d & e & f & g \\
\hline $\mathrm{Na}_{2} \mathrm{O}$ & 2.43 & 1.05 & 0.46 & - & 0.23 & 0.8 & 0.5 & 2.35 \\
\hline $\mathrm{MgO}$ & 1.55 & 1.05 & 7.98 & 5.22 & 4.04 & 5.42 & 4.95 & 7.06 \\
\hline $\mathrm{Al}_{2} \mathrm{O}_{3}$ & 4.76 & 4.09 & 9.26 & 8.24 & 7.06 & 6.08 & 1.10 & 1.69 \\
\hline $\mathrm{SiO}_{2}$ & 44.41 & 39.63 & 51.69 & 50.81 & 48.03 & 49.27 & 50.31 & 50.65 \\
\hline $\mathrm{K}_{2} \mathrm{O}$ & 0.57 & 0.61 & 0.75 & 1.27 & 1.95 & 1.45 & 0.8 & 0.70 \\
\hline $\mathrm{CaO}$ & 0.73 & 0.42 & 0.32 & - & 0.64 & 0.69 & 1.13 & 0.91 \\
\hline $\mathrm{TiO}_{2}$ & 1.44 & 0.84 & & & & 0.46 & & \\
\hline $\mathrm{Fe}_{2} \mathrm{O}_{3}$ & 24.01 & 32.37 & 9.85 & 14.4 & 18.05 & 15.8 & 21.2 & 16.63 \\
\hline \multicolumn{9}{|c|}{ Tetrahedral } \\
\hline $\mathrm{Si}$ & 3.75 & & 3.95 & 3.96 & 3.85 & 3.94 & 4.06 & 4.06 \\
\hline Al & 0.25 & & 0.05 & 0.04 & 0.15 & 0.06 & & \\
\hline \multicolumn{9}{|c|}{ Octohedral } \\
\hline $\mathrm{Al}_{3}$ & 0.23 & & 0.78 & 0.72 & 0.51 & 0.51 & 0.11 & 0.15 \\
\hline $\mathrm{Fe}^{3+}$ & 1.52 & & 0.57 & 0.85 & 1.10 & 0.95 & 1.29 & 1.00 \\
\hline $\mathrm{Mg}$ & 0.19 & & 0.91 & 0.60 & 0.48 & 0.64 & 0.60 & 0.84 \\
\hline \multicolumn{9}{|c|}{ Interlayer } \\
\hline $\mathrm{Na}$ & 0.40 & & 0.06 & & 0.04 & 0.12 & 0.08 & 0.37 \\
\hline $\mathrm{K}$ & 0.06 & & 0.07 & 0.12 & 0.20 & 0.14 & 0.08 & 0.07 \\
\hline $\mathrm{Ca}$ & 0.07 & & 0.03 & - & 0.06 & 0.06 & 0.10 & 0.09 \\
\hline $\mathrm{Mg}$ & - & & - & - & - & - & - & - \\
\hline
\end{tabular}

Note: a, pale botryoid; b, brown botryoid; c, core clay; d, cortex green clay; e, green clay from the cracks; $f$, outer green clay; $g$, surrounding sediment green clay.

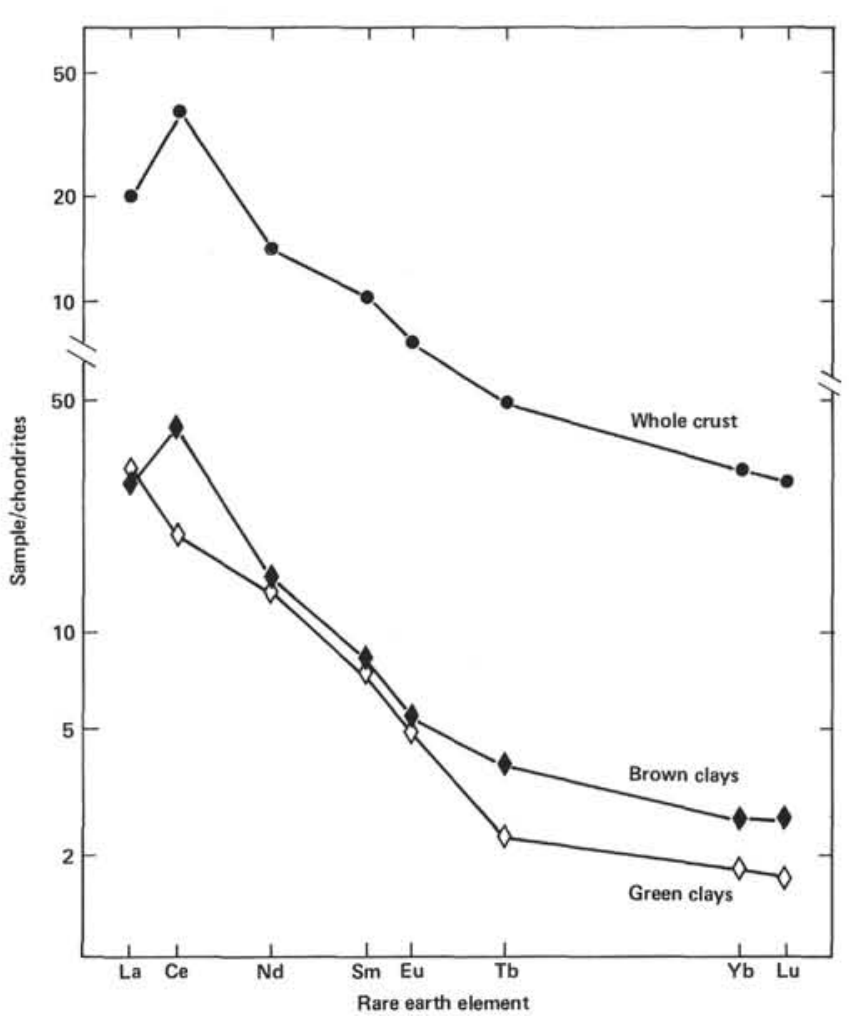

Figure 7. REE abundance patterns of nodule and surrounding concretions from Hole 553A.

The green clays have approximately the same distribution and the same REE absolute concentrations as brown clays, but the $\mathrm{Ce}$ enrichment does not exist.

\section{Hole 554}

At $2584 \mathrm{~m}$ water depth, $119 \mathrm{~m}$ below the sediment/ water interface, an unconformity between the early and late Eocene, represented by an $11-\mathrm{cm} \mathrm{Mn}$-rich layer was recovered (Fig. 2). The stratigraphic position corresponds to the NP19-20 biozone. This level is principally made of two types of concretions:

1. Debris of a nodule (Plate 7, Fig. 1);

2. Aggregates of $\mathrm{Fe}-\mathrm{Mn}$ micronodules and indurated sediment formed by biogenic carbonate and phosphatic debris (fish teeth) which are encrusted by $\mathrm{Fe}-\mathrm{Ti}$ and filled with green clays, phillipsite, detrital minerals (feldspars, pyroxenes, olivine, ilmenite, chromite), and epiclastic basaltic fragments.

The nodule fragments have typical botryoidal $\delta \mathrm{MnO}_{2}$ structures. Some feldspars remain in the structure and $\mathrm{SiO}_{2}$ content is high. $\mathrm{Ni}$ and $\mathrm{Cu}$ are in low concentrations in the Mn-rich zones but Co is not detected (Table 9). X-ray patterns show the 060 dioctahedral smectites reflection associated with $\delta \mathrm{MnO}_{2}$ reflections (Fig. 5B).

The micronodules (up to $0.5 \mathrm{~mm}$ diameter) have an onionlike structure or a massive fibrous structure (Plate 8, Figs. 2-4); they are formed by a well-crystallized todorokite (Fig. 8). Mn concentrations are always very high $(\mathrm{MnO}>50 \%)$ with $\mathrm{Mn} / \mathrm{Fe}>25$. Transition elements $\mathrm{Ni}$ and $\mathrm{Cu}(\mathrm{Ni}+\mathrm{Cu}$ up to $3 \%)$ occur in the onionlike structures but do not appear in the massive structures. $\mathrm{Co}$ is not detected, and $\mathrm{Ba}$ concentrations are low. 
Table 9. Chemical compositions of Mn phases and structural formulas of smectites calculated on 11 oxygens, Hole 554A concretions.

\begin{tabular}{|c|c|c|c|c|c|c|c|c|c|c|}
\hline \multirow[b]{3}{*}{$\mathrm{Na}_{2} \mathrm{O}$} & \multicolumn{3}{|c|}{ Cortex fragment } & \multicolumn{5}{|c|}{ Micronodules } & \multicolumn{2}{|c|}{ Green clay } \\
\hline & \multicolumn{2}{|c|}{$\mathrm{Fe}>\mathrm{Mn}$} & \multirow[t]{2}{*}{$\mathrm{Fe}<\mathrm{Mn}$} & \multicolumn{2}{|c|}{$\begin{array}{l}\text { Onionlike } \\
\text { structure }\end{array}$} & \multicolumn{3}{|c|}{ Fibrous structure } & \multirow[t]{2}{*}{$a_{1}$} & \multirow[t]{2}{*}{$a_{2}$} \\
\hline & 0.81 & 0.98 & & & 2.7 & & & & & \\
\hline $\mathrm{MgO}$ & 1.98 & 2.31 & 2.81 & 7.2 & 6.05 & 6.47 & 2.87 & 5.5 & 3.02 & 3.51 \\
\hline $\mathrm{Al}_{2} \mathrm{O}_{3}$ & 5.83 & 4.20 & 3.50 & 4.29 & 1.85 & 5.24 & 0.8 & 3.49 & 6.76 & 9.08 \\
\hline $\mathrm{SiO}_{2}$ & 40.93 & 34.02 & 19.04 & 5.07 & 0.8 & 1.13 & 0.38 & 1.43 & 46.74 & 48.49 \\
\hline $\mathrm{K}_{2} \mathrm{O}$ & 0.32 & 0.48 & 0.24 & 0.64 & 1.09 & 0.71 & 1.32 & 1.18 & 2.90 & 1.76 \\
\hline $\mathrm{CaO}$ & 1.62 & 2.14 & 3.47 & 1.7 & 0.96 & 1.19 & 0.9 & 1.12 & 0.53 & 0.88 \\
\hline $\mathrm{TiO}_{2}$ & 1.06 & 1.16 & N.D. & & & & & & & \\
\hline MnO & 11.06 & 12.25 & 29.92 & 55.13 & 62.70 & 60.49 & 69.85 & 64.46 & & 0.25 \\
\hline $\mathrm{Fe}_{2} \mathrm{O}_{3}$ & 16.24 & 20.7 & 18.54 & 1.74 & 0.20 & 1.72 & 0.33 & 1.48 & 20.04 & 16.01 \\
\hline $\mathrm{NiO}$ & & 0.1 & 0.38 & 2.62 & 0.62 & & & & & \\
\hline $\mathrm{CuO}$ & & 0.1 & 0.37 & 0.6 & 0.61 & & 0.1 & & & \\
\hline $\mathrm{BaO}$ & & & & 1.01 & 2.42 & & 3.53 & 1.37 & & \\
\hline \multicolumn{11}{|c|}{ Tetrahedral } \\
\hline $\mathrm{Si}$ & & & & & & & & & 3.81 & 3.86 \\
\hline Al & & & & & & & & & 0.19 & 0.14 \\
\hline \multicolumn{11}{|c|}{ Octahedral } \\
\hline Al & & & & & & & & & 0.46 & 0.71 \\
\hline $\mathrm{Fe}$ & & & & & & & & & 1.22 & 0.95 \\
\hline $\mathrm{Mg}$ & & & & & & & & & 0.37 & 0.41 \\
\hline \multicolumn{11}{|c|}{ Interlayer } \\
\hline $\mathrm{Na}$ & & & & & & & & & - & - \\
\hline K & & & & & & & & & 0.30 & 0.18 \\
\hline $\mathrm{Ca}$ & & & & & & & & & 0.05 & 0.07 \\
\hline $\mathrm{Mg}$ & & & & & & & & & - & - \\
\hline
\end{tabular}

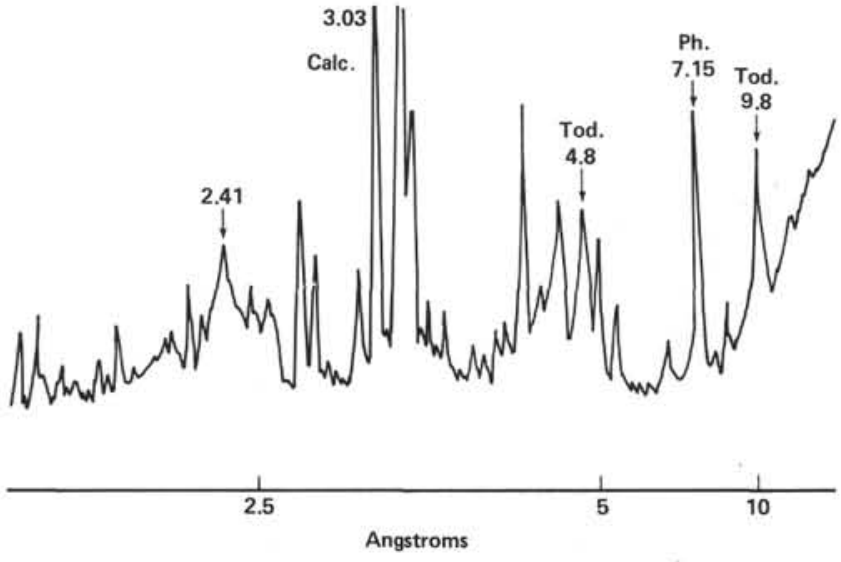

Figure 8. X-ray diffraction patterns of Hole 554A Mn concretions. Well-crystallized todorokite and abundant phillipsite.
The zeolites associated with the micronodules are $\mathrm{K}$, $\mathrm{Na}$, and $\mathrm{Ca}$ phillipsites and clinoptilolites (Table 10), with $\mathrm{Si} / \mathrm{Al}=2.9$ for the phillipsites and $\mathrm{Si} / \mathrm{Al}=4.25$ for the clinoptilolites (Plate 7, Fig. 5). The fillings of the biogenic structures (Plate 7, Fig. 6) are composed of $\mathrm{Na}-$ $\mathrm{K}$ phillipsites or of smectites that have a chemical composition (Table 9, $a_{1}, a_{2}$ ) close to the green clays of nodules from Holes 552 and 553 .

\section{COMPARISON AMONG MINERALOGICAL FACIES}

\section{Sedimentary Material}

\section{Biogenic Material}

The biogenic debris present essentially in the nodules from Holes 552 and 553 is or was essentially carbonate

Table 10. Chemical compositions of zeolites.

\begin{tabular}{|c|c|c|c|c|c|c|c|c|c|}
\hline \multirow[b]{3}{*}{$\mathrm{Na}_{2} \mathrm{O}$} & \multicolumn{4}{|c|}{ Hole $552 \mathrm{~A}$} & \multicolumn{2}{|c|}{ Hole $553 \mathrm{~A}$} & \multicolumn{3}{|c|}{ Hole 554A } \\
\hline & \multicolumn{2}{|c|}{ a } & \multicolumn{2}{|c|}{ b } & \multirow{2}{*}{$\frac{c}{4.67}$} & \multirow{2}{*}{$\begin{array}{c}\mathrm{d} \\
6.57\end{array}$} & \multirow{2}{*}{$\begin{array}{c}\mathrm{e} \\
4.80\end{array}$} & \multirow{2}{*}{$\begin{array}{c}\text { f } \\
4.98\end{array}$} & \multirow{2}{*}{$\frac{\mathrm{g}}{1.48}$} \\
\hline & 6.15 & 6.30 & 4.83 & 4.52 & & & & & \\
\hline $\mathrm{Al}_{2} \mathrm{O}_{3}$ & 16.10 & 15.9 & 17.51 & 16.43 & 16.56 & 16.54 & 16.65 & 16.52 & 13.09 \\
\hline $\mathrm{SiO}_{2}$ & 58.60 & 58.11 & 56.16 & 58.48 & 57.70 & 57.49 & 56.74 & 56.9 & 65.89 \\
\hline $\mathrm{K}_{2} \mathrm{O}$ & 3.72 & 4.66 & 5.6 & 4.83 & 5.68 & 3.64 & 6.03 & 5.42 & 2.51 \\
\hline $\mathrm{CaO}$ & - & - & - & - & - & - & - & 1.29 & 2.32 \\
\hline $\mathrm{Fe}_{2} \mathrm{O}_{3}$ & 0.97 & - & 0.85 & 0.74 & 0.36 & 0.8 & 0.73 & - & - \\
\hline
\end{tabular}


material: foraminifers and nannofossils. At the top of the nodule from Hole 552, foraminifers are filled either by green clays or by Mn oxide or both together (Plate 2, Fig. 1). The nannofossils are mixed with phillipsites and smectites and are still quite recognizable. They are also well preserved in the white clays from the cracks. In green clays, only some foraminiferal "tests" remain but the major part is dissolved, as are the coccoliths. The carbonate dissolution also exists in the green clay situated in the external zone of the nodule from Hole 553. In the nucleus of this nodule, biogenic "tests" are replaced by phillipsite (Plate 4 Fig. 2).

\section{Lithogenous Material}

The nucleus of the nodule from Hole 552 is mainly composed of smectites and shows several cavities whose morphology looks like old volcanic glass. The REE pattern has a fractionation similar to those occurring elsewhere in volcanogenic materials that have been differentiated with regard to LREE-depleted typical deep-oceanic tholeiites (Frey and Haskin, 1964; Gast, 1968; Joron et al., this volume). Moreover, the positive $\mathrm{Ce}$ anomaly indicates that the transformation took place in an oxidizing medium since it has already been recorded in palagonitization processes in other Deep Sea Drilling Project (DSDP) holes (Frey et al., 1974; Ludden and Thompson, 1978, 1979; Juteau et al., 1980; Bonnot-Courtois, 1980). The clay would come partly from the transformation of volcanogenic material, with progressive increase in the crystallinity until smectite formation, e.g., the coating of cavities.

We tried to detect the origin of the volcaniclastic materials from the geochemistry of hygromagmaphile (Th, $\mathrm{Ta}, \mathrm{Hf}, .$.$) elements, which are indicators of mantle ori-$ gin (Joron and Treuil, 1977; Joron et al., 1978). The results, together with REE data (Desprairies et al., this volumn), lead to consideration of an "emerged" oceanic area, which could be the Island-Faeroe Ridge, during the nodule-formation period (Donn and Ninkovitch, 1980; Sigurdsson and Loebner, 1981; Grousset et al., 1982).

All the crustal zones of the nodules from the three holes have high $\mathrm{Si}-\mathrm{Al}$ contents, since they incorporated various quantities of smectites, especially in Holes 553 and 554. The REE distributions of the nodules from Holes 552 and 553 are quite different. The nodule cortex from Hole 553 has a low REE content and a weak $\mathrm{Ce}$ anomaly, contrary to the high concentrations and positive $\mathrm{Ce}$ anomaly of the Hole 552 nodule, which is similar to the characteristics of recent polymetallic nodules.

Detrital clays are found with biogenic tests in the cracks of the nodules. (Plate 5, Figs. 3, 4,).

Feldspars and quartz are found together in the cortex of the nodules from all three holes and also in the cracks of the Hole 552 concretion, but quartz is absent in the nucleus of the Hole 552 nodule.

\section{Mn Oxides}

\section{The " $\delta \mathrm{MnO}_{2}$ "}

The nodule from Hole 552 and the fragments of nodule from Hole 554 are formed by poorly crystallized hy- drated Mn oxide, mixed with Fe-rich phases and silicates: this association corresponds to " $\delta \mathrm{MnO}_{2}$ " (Cronan and Tooms, 1969). The chemical composition shows greater quantities of $\mathrm{Si}-\mathrm{Al}$ in the Hole 554 nodule, which is in other respects depleted in $\mathrm{Cu}$ and $\mathrm{Ni}$ (three times lower), and where Co is not detected $(<1000$ ppm). Recent Atlantic nodules also show great variation in their chemical composition, especially for transition elements (Cronan, 1975).

\section{Todorokite}

As in nodules present on the deep-sea floor, the Mnrich layers from the Hole 552 fossil nodule (Plate 4, Fig. 2) contain todorokite. This mineral also occurs at the surface and in the cracks of this nodule, as well as in the concretions enriched in zeolites from Hole 554, where it is well crystallized. Transition elements $\mathrm{Co}+\mathrm{Ni}+\mathrm{Cu}$ are included in the microlaminated structures (up to $3 \%$ in the richer phases) but are absent in the fibrous massive structures. High $\mathrm{Ba}$ concentrations $(\mathrm{BaO}=9 \%)$ are found at the top of the Hole 552 nodule. The optic reflectance of the Ba-rich oxides is that of psilomelane (Perseil, pers. comm.). $\mathrm{Si} / \mathrm{Al}$ ratio is always above one in typical microlaminated structures and in Mn-rich layers, and below one in Mn-oxides from the cracks, which can present very low $\mathrm{Si}$ concentration (inferior to $1 \%$ ). $\mathrm{Mg}$ concentrations are always high.

\section{The Green Clays}

Green clays occur in the three holes: for the Hole 552 nodule, in the cracks and the external part; for Hole 553 nodule, in all the different facies described; and for the Hole 554 concretions, they fill the biogenic structures. Their chemical compositions are sometimes close to those observed for nontronites found in typical oceanic hydrothermal deposits. The $\mathrm{Al}$ and $\mathrm{Fe}$ contents permit distinction between green clays and lithogenic clays, but the $\mathrm{K}$ concentrations (Fig. 9) are too low to lead to glauconite $\left(\mathrm{K}_{2} \mathrm{O} \sim 2 \%\right)$. Furthermore, polished-section studies give a $\mathrm{Mg} / \mathrm{Al}$ ratio close to one whereas analyses of phyllites give a $\mathrm{Mg} / \mathrm{Al}$ ratio of three. This phenomenon represents a mixing of smectites.

\section{The Zeolites}

Phillipsites are common in the three holes. They are abundant in the botryoidal structures and have invaded the void created by the dissolution of organisms. In the Hole 552 nodule cracks, the phillipsites are associated with Mn precipitations. The chemical composition always leads to $\mathrm{Na}-\mathrm{K}$ phillipsites with high $\mathrm{Si} / \mathrm{Al}$ ratios equal to the ratios given by Stonecipher (1978). When clinoptilolite is also present in Hole 554, the phillipsites contain more $\mathrm{Ca}$.

\section{STATISTICAL STUDY OF GEOCHEMICAL DATA}

This study of the repartition of nine major elements (Si, Ti, $\mathrm{Al}, \mathrm{Fe}, \mathrm{Mg}, \mathrm{Mn}, \mathrm{Ca}, \mathrm{Na}$, and $\mathrm{K}$ ) has three objectives:

1. Comparison of the two best-preserved nodules, the first one Mn-bearing (Site 552); the second one, Fe-enriched clay (Site 553); 


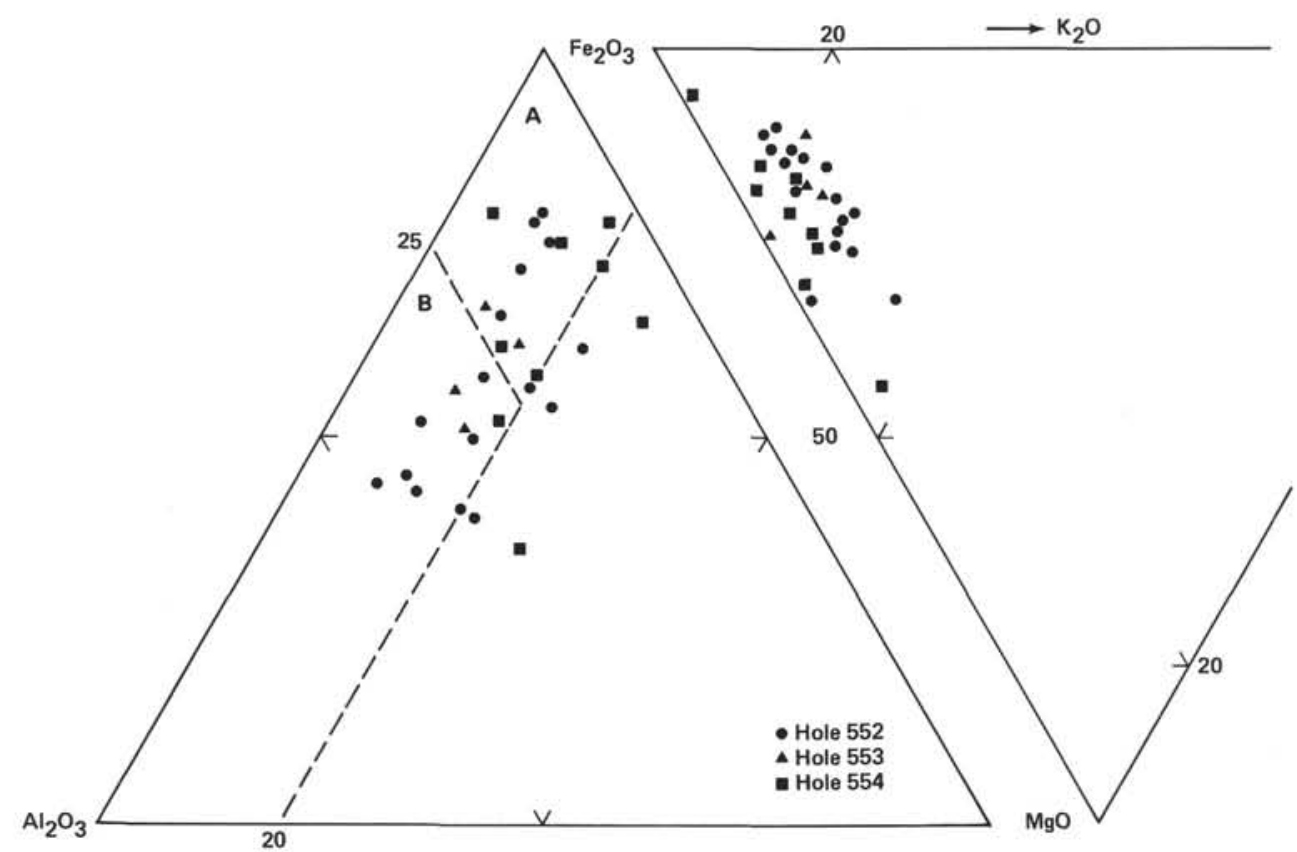

Figure 9. $\mathrm{Al}_{2} \mathrm{O}_{3}-\mathrm{Fe}_{2} \mathrm{O}_{3}-\mathrm{MgO}$ and $\mathrm{MgO}-\mathrm{Fe}_{2} \mathrm{O}_{3}-\mathrm{K}_{2} \mathrm{O}$ ternary diagrams showing the chemistry of smectites in Hole 552A, 553A and 554A concretions. Note that fields $\mathrm{A}$ (nontronite) and $\mathrm{B}$ (iron-rich beidellite) are not distinguishable on the basis of their $\mathrm{K}_{2} \mathrm{O}$ content.

2. Identification of the geochemical facies typical of the different phases composing the two nodules;

3. Investigation of the eventual geochemical relationships in and between six observed morphological units: the core of the first Mn-bearing nodule (A), its Mn crust (B) cut by diagenetic oxides (C) and sediment infilled concentric (D) or radial (E) cracks that have to be compared with the second, Mn-less nodule (F).

To avoid mixing the primary determinations of the existing elements with the various remaining factors that enter the $100 \%$ difference of the microprobe analysis (texture, clay fraction wetness, significant concentrations of trace elements, etc.) raw data figures were used in the calculation. The data were plotted by a factorial analysis using normed principal components (Lebart et al. 1977 ) with triangular projections and specific treatment of each of the morphological units for clearness of partial and total correlations between major elements.

\section{Principal-Component Analysis ${ }^{3}$}

In this calculation of four factors, the two first (plane $F_{1} F_{2}$ ) correspond to $60 \%$ (Table 11 ) of the total variance of the system.

Variable results show that $\operatorname{six}(\mathrm{Si}, \mathrm{Al}, \mathrm{K}, \mathrm{Mg}, \mathrm{Mn}$ and $\mathrm{Fe}$ ) of the nine initial variables, situated near the correlation circle (Fig. 10), are well represented on the plane $\left(F_{1}, F_{2}\right)$. The first factor $\left(F_{1}\right)$ shows an $\mathrm{Al}-\mathrm{Si}$ phase opposite to a complex precipitated $\mathrm{Fe}-\mathrm{Mn}$ phase. The second factor $\left(F_{2}\right)$ shows a strong negative correlation between $\mathrm{Fe}$ and $\mathrm{Mn}$. The $F_{1}-F_{2}$ projection distinguishes an opposite relationship between $\mathrm{Ca}$ and the silicate phase,

\footnotetext{
${ }^{3}$ Genstat Programs, UNIVAC, Paris Sud Informatique, Orsay (France).
}

Table 11. Proper values.

\begin{tabular}{cccc}
\hline & & $\begin{array}{c}\text { Percentage } \\
\text { Fatent } \\
\text { rooplicated } \\
\text { variance }\end{array}$ & $\begin{array}{c}\text { Cumulative } \\
\text { percentage }\end{array}$ \\
\hline 1 & 3.16 & 35.12 & 35.12 \\
2 & 2.16 & 23.98 & 59.10 \\
3 & 1.40 & 15.56 & 74.66 \\
4 & 0.83 & 9.21 & 83.87 \\
\hline
\end{tabular}

a positive correlation between $\mathrm{Ti}$ and $\mathrm{Fe}$, and a specific behavior of $\mathrm{Mg}$ that is opposite to $\mathrm{Fe}$ and related to $\mathrm{Mn}$ and to $\mathrm{Al}-\mathrm{K}$, representing silicates.

Studied morphological units enclose one or sometimes several phases having different geochemical characteristics. In some cases, the geochemical facies could be very similar and a superposition occurs (Fig. 11). Samples can be divided into six groups:

1. Quadrant IV: a lithogenous silicate phase $(\mathrm{Si}, \mathrm{Al}$, $\mathrm{K})$ corresponds to the nucleus of the nodule from Hole 552 (A).

2. A bipolar oblique unit represents the clays filling the cracks (E) of the Hole 552 nodule corresponding to lithogenous silicates and diagenetic phases.

3. Samples of detrital and/or diagenetic origin are gathered near the axis origin. $\mathrm{Si}, \mathrm{Al}, \mathrm{Mg}$, and $\mathrm{Fe}$ concentrations vary and represent the sediments that fill radial cracks (E) and clays from the concentric cracks (D) of the Hole 552 nodule. Projections of the Hole 553 samples fall in the same area.

4. Quadrant I: the most Fe-rich pole represents typical botryoids of the Mn nodule (B). This family, relatively $\mathrm{Ca}$ rich, can be divided into two groups: one enriched in Ti with highest $F_{2}$ axis, the other one Ti-poor but $\mathrm{Mn}$ richer, near the $F_{1}$ axis. 


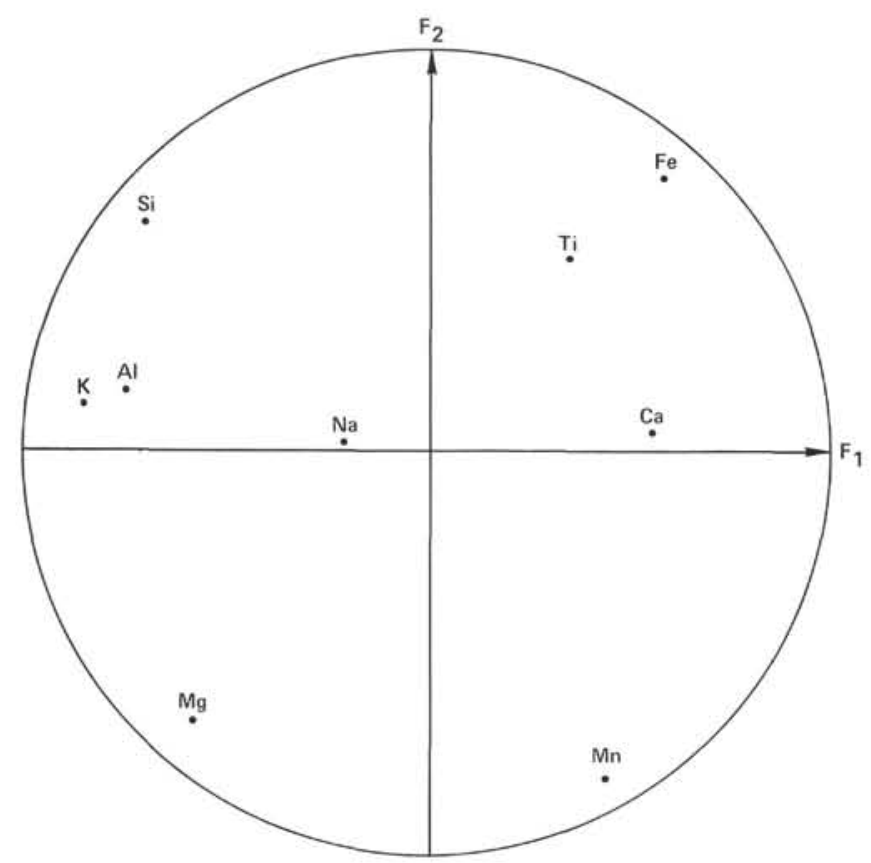

Figure 10. Principal-component analysis. Correlation circle of unit (1) radius (major elements). Plane $\mathrm{F}_{1}, \mathrm{~F}_{2}$.

5. Two groups appear in quadrant II and correspond to the Mn oxides of the Hole 552 nodule. The botryoidal laminations (F) fall onto the Mn direction, and the Mn-oxide grains (C), located in the cracks, fall onto the second factor axis between $\mathrm{Mg}$ and $\mathrm{Mn}$ directions.

The mean values and their related $90 \%$ confidencelevel variation interval calculated for each of the morphological units express these geochemical differences and similarities: the core of the first nodule (Site 552), characterized by its high $\mathrm{Si}-\mathrm{Al}$ content but also relatively abundant $\mathrm{Ti}$ and $\mathrm{Ca}$, contrasts with the other Mnless classes that are rather $\mathrm{Al}$-poor, Fe-rich materials. The cation-ratio table (Table 12) stresses the geochemical resemblance of the Site 553 nodule's cortex and the material infilling the Site 552 nodule's cracks. The difference between the Fe-rich botryoids and Fe-depleted Mn-rich diagenetic oxides reflects the $\mathrm{Fe}-\mathrm{Mn}$ opposition of the metalliferous material whose $\mathrm{Fe}$ and/or $\mathrm{Mn}$ gain is compensated by a diminution in $\mathrm{Si}, \mathrm{Al}$, and $\mathrm{K}$ content. However, the still significant quantities of these elements show, in both cases, the persistence of a silicate frame.

\section{Ternary Diagrams}

\section{Si-Ti-Mn Projection (Fig. 12A)}

Along the Si-Ti side, the Ti-rich core of the first nodule separates from the Ti-poorer Mn-less sediments. In the middle of the diagram, the Mn botryoids' triangle stretches from a Ti-Si rich side to a Mn-enriched apex, showing the two subclasses of this fraction. Near the $\mathrm{Mn}$ pole, the cluster of Mn oxides presents a separation gap between the Mn-richer oxide grains and the more $\mathrm{Si}-\mathrm{Ti}$ associated botryoidal laminations. The differences in the respective position of the Mn-less class here con- trast the $\mathrm{Ti}$ behavior to that of $\mathrm{Fe}$. $\mathrm{Ti}$ is in fact more concentrated in the core of the first nodule than in the other Mn-less sediments, and the remaining broad $\mathrm{Si} / \mathrm{Ti}$ ratio variability accompanying the Mn-content increase of the botryoids partially reflects the variation of $\mathrm{Ti}$ from this nodule's core toward its outer cortex.

\section{Fe-Mn-Mg Projection (Fig. 12B)}

The Mn sediments (along the Fe-Mn side) completely exclude themselves from the Mn-less ones (along the $\mathrm{Fe}-$ $\mathrm{Mg}$ side), both showing independent Fe gains. Symetrical to the $\mathrm{Fe}-\mathrm{Mg}$ opposition in the clay fractions, an $\mathrm{Fe}-$ Mn competition appears in the Mn fractions. The stability of the $\mathrm{Mn} / \mathrm{Mg}$ ratio during the $\mathrm{Fe}$ invasion underlies the opposition of the $\mathrm{Fe}$ content increase to its conjoint $\mathrm{Mn}-\mathrm{Mg}$ gain. As a result of their lower Fe content, the $\mathrm{Mn}$ oxides show a lower $\mathrm{Fe} /(\mathrm{Mn}+\mathrm{Mg})$ ratio combined with a slight $\mathrm{Mn} / \mathrm{Mg}$ ratio diminution in the $\mathrm{Mn}-\mathrm{Mg}$ richer oxide grains.

\section{$\mathrm{Fe}-\mathrm{Al}-\mathrm{Mg}$ Projection (Fig. 12C)}

This Mn-independent diagram reveals the geochemical trends of the clay Mn-less sediments. The core of the Site 552 nodule consists of mainly aluminous material susceptible to a slight conjoint $\mathrm{Mg}-\mathrm{Fe}$ gain keeping the $\mathrm{Fe} / \mathrm{Mg}$ ratio constant. Although less aluminous than the core, the material infilling the radial cracks and part of the sediment in the concentric cracks of this nodule's cortex follow a similar evolution. The rest of the concentric infilling corresponds to authigenic clays containing slightly more $\mathrm{Mg}$ and much more $\mathrm{Fe}$ than the latter $\mathrm{Mg}-\mathrm{Fe}$-enriched but still aluminous sediment. The Site $553 \mathrm{Mn}$-less nodule is made of two kinds of material: Fe-rich botryoids close, on this projection, to those of the Site 552 nodule and authigenic $\mathrm{Fe}-\mathrm{Mg}$-rich clays which plot here parallel to the $\mathrm{Mg}-\mathrm{Fe}$ side, near the authigenic clays of the Site 552 nodule's cracks (green clay facies) and seem equally derived from a more aluminous material.

The Mn phases separate in two opposing clusters. The main trend of the botryoids follows a line parallel to the $\mathrm{Al}-\mathrm{Fe}$ side as the silicate frame is invaded by the $\mathrm{Fe}$ fraction with, at the end of this evolution, a diverging $\mathrm{Fe}-$ $\mathrm{Mg}$ side parallel branch denoting indirectly the $\mathrm{Fe}-(\mathrm{Mn}$ $+\mathrm{Mg}$ ) competition. The Mn-oxide projections, parallel to the $\mathrm{Fe}-\mathrm{Mg}$ side, point toward the $\mathrm{Mg}$ pole, as their low $\mathrm{Al}$ silicate frame coexists with the more and more abundant $(\mathrm{Mn}+\mathrm{Mg})$ oxide complex.

\section{Interelement Correlations}

Specific examination of the correlation pattern of the morphological unit allows us to confirm and bring minute shades of meaning to the preceding global analysis. In addition to the total correlation coefficients, a multivariate regression analysis of the Gauss-normalized data yielded partial correlation coefficients more representative of the intrinsic relationships between the elements in each couple (Rivière, 1969). A graphic representation of the whole set of statistically significant correlations facilitates the comparison and interpretation of the obtained correlation patterns (Fig. 13). 




Figure 11. Graphical representation of samples and variable directions on the plane $\left(\mathrm{F}_{1}, \mathrm{~F}_{2}\right)$, showing the geochemical differences and similarities between the morphological units.

Table 12. Mean values $\bar{x}$ and $2 \sigma$ for major elements and main cation ratios of the six morphological units (see text). In parentheses, number of determinations for each column.

\begin{tabular}{|c|c|c|c|c|c|c|c|c|c|c|c|c|}
\hline & \multicolumn{2}{|c|}{ A (13) } & \multicolumn{2}{|c|}{ B (47) } & \multicolumn{2}{|c|}{$C(27)$} & \multicolumn{2}{|c|}{ D (12) } & \multicolumn{2}{|c|}{ E (18) } & \multicolumn{2}{|c|}{$F(12)$} \\
\hline & $\overline{\mathrm{x}}$ & $2 \sigma$ & $\overline{\mathrm{x}}$ & $2 \sigma$ & $\overline{\mathrm{x}}$ & $2 \sigma$ & $\bar{x}$ & $2 \sigma$ & $\overline{\mathrm{x}}$ & $2 \sigma$ & $\overline{\mathrm{x}}$ & $2 \sigma$ \\
\hline \multicolumn{13}{|c|}{ Major elements } \\
\hline $\mathrm{SiO}_{2}$ & 49.12 & 2.21 & 22.45 & 0.64 & 11.07 & 2.83 & 36.23 & 4.85 & 45.18 & 3.05 & 44.00 & 3.33 \\
\hline $\mathrm{TiO}_{2}$ & 2.37 & 0.62 & 2.56 & 0.38 & 0.67 & 0.29 & 0.27 & 0.13 & 0.47 & 0.13 & 0.69 & 0.21 \\
\hline $\mathrm{Al}_{2} \mathrm{O}_{3}$ & 12.73 & 1.69 & 4.43 & 0.33 & 5.00 & 1.30 & 4.71 & 0.82 & 7.69 & 0.55 & 4.53 & 1.52 \\
\hline $\mathrm{Fe}_{2} \mathrm{O}_{3}$ & 16.01 & 1.50 & 34.16 & 1.32 & 13.03 & 4.40 & 18.22 & 4.05 & 22.68 & 2.30 & 22.72 & 4.42 \\
\hline $\mathrm{MgO}$ & 3.79 & 0.28 & 1.16 & 0.08 & 4.81 & 0.80 & 2.80 & 0.41 & 4.16 & 0.50 & 2.65 & 0.98 \\
\hline $\mathrm{CaO}$ & 0.98 & 0.17 & 2.12 & 0.12 & 1.82 & 0.32 & 0.93 & 0.40 & 1.60 & 0.48 & 1.35 & 0.68 \\
\hline $\mathrm{Na}_{2} \mathrm{O}$ & 1.49 & 0.23 & 0.83 & 0.11 & 0.97 & 0.19 & 0.43 & 0.22 & 0.97 & 0.10 & 1.11 & 0.36 \\
\hline $\mathrm{K}_{2} \mathrm{O}$ & 2.72 & 0.28 & 0.40 & 0.03 & 0.69 & 0.19 & 1.07 & 0.26 & 2.19 & 0.22 & 1.12 & 0.57 \\
\hline $\mathrm{MnO}$ & 0.30 & 0.07 & 12.47 & 0.99 & 39.62 & 5.68 & 0.66 & 0.32 & 1.12 & 0.23 & 0.34 & 0.27 \\
\hline \multicolumn{13}{|c|}{ Main cation ratios } \\
\hline $\mathrm{Si} / \mathrm{Al}$ & \multicolumn{2}{|c|}{5.34} & \multirow{2}{*}{\multicolumn{2}{|c|}{7.02}} & \multicolumn{2}{|c|}{3.07} & \multirow{2}{*}{\multicolumn{2}{|c|}{10.65}} & \multirow{2}{*}{\multicolumn{2}{|c|}{8.14}} & \multicolumn{2}{|c|}{13.45} \\
\hline $\mathrm{Si} / \mathrm{Fe}$ & \multirow{2}{*}{\multicolumn{2}{|c|}{$\begin{array}{r}3.21 \\
15.84\end{array}$}} & & & \multirow{2}{*}{\multicolumn{2}{|c|}{$\begin{array}{l}0.89 \\
281\end{array}$}} & & & \multirow{2}{*}{\multicolumn{2}{|c|}{2.09}} & \multirow{2}{*}{\multicolumn{2}{|c|}{$\begin{array}{r}2.03 \\
20.29\end{array}$}} \\
\hline $\mathrm{Si} / \mathrm{Mg}$ & & & \multicolumn{2}{|c|}{$\begin{array}{r}0.69 \\
25.63\end{array}$} & & & \multicolumn{2}{|c|}{2.08} & & & & \\
\hline $\mathrm{Si} / \mathrm{Ti}$ & \multicolumn{2}{|c|}{25.33} & \multicolumn{2}{|c|}{10.72} & \multicolumn{2}{|c|}{20.19} & \multicolumn{2}{|c|}{$\begin{array}{r}15.81 \\
164.00\end{array}$} & \multicolumn{2}{|c|}{$\begin{array}{r}13.27 \\
117.48\end{array}$} & \multicolumn{2}{|c|}{77.94} \\
\hline $\mathrm{Al} / \mathrm{Fe}$ & \multicolumn{2}{|c|}{0.60} & \multicolumn{2}{|c|}{0.10} & \multicolumn{2}{|c|}{0.29} & \multicolumn{2}{|c|}{0.20} & \multicolumn{2}{|c|}{0.26} & & 15 \\
\hline $\mathrm{Al} / \mathrm{Mg}$ & 2.9 & & & & 0.5 & & & 48 & & 63 & & 51 \\
\hline $\mathrm{Al} / \mathrm{Ti}$ & 4.7 & & & & 6.5 & & 15. & & & 44 & & 79 \\
\hline $\mathrm{Fe} / \mathrm{Mg}$ & 4.9 & & 34. & & 3.1 & & & 59 & & 36 & 10. & \\
\hline $\mathrm{Fe} / \mathrm{Ti}$ & 7.8 & & 15. & & 22. & & 78 & 73 & & 30 & 38. & \\
\hline $\mathrm{Mg} / \mathrm{Ti}$ & 1.6 & & & & 7.1 & & 10. & & & .85 & & 84 \\
\hline
\end{tabular}



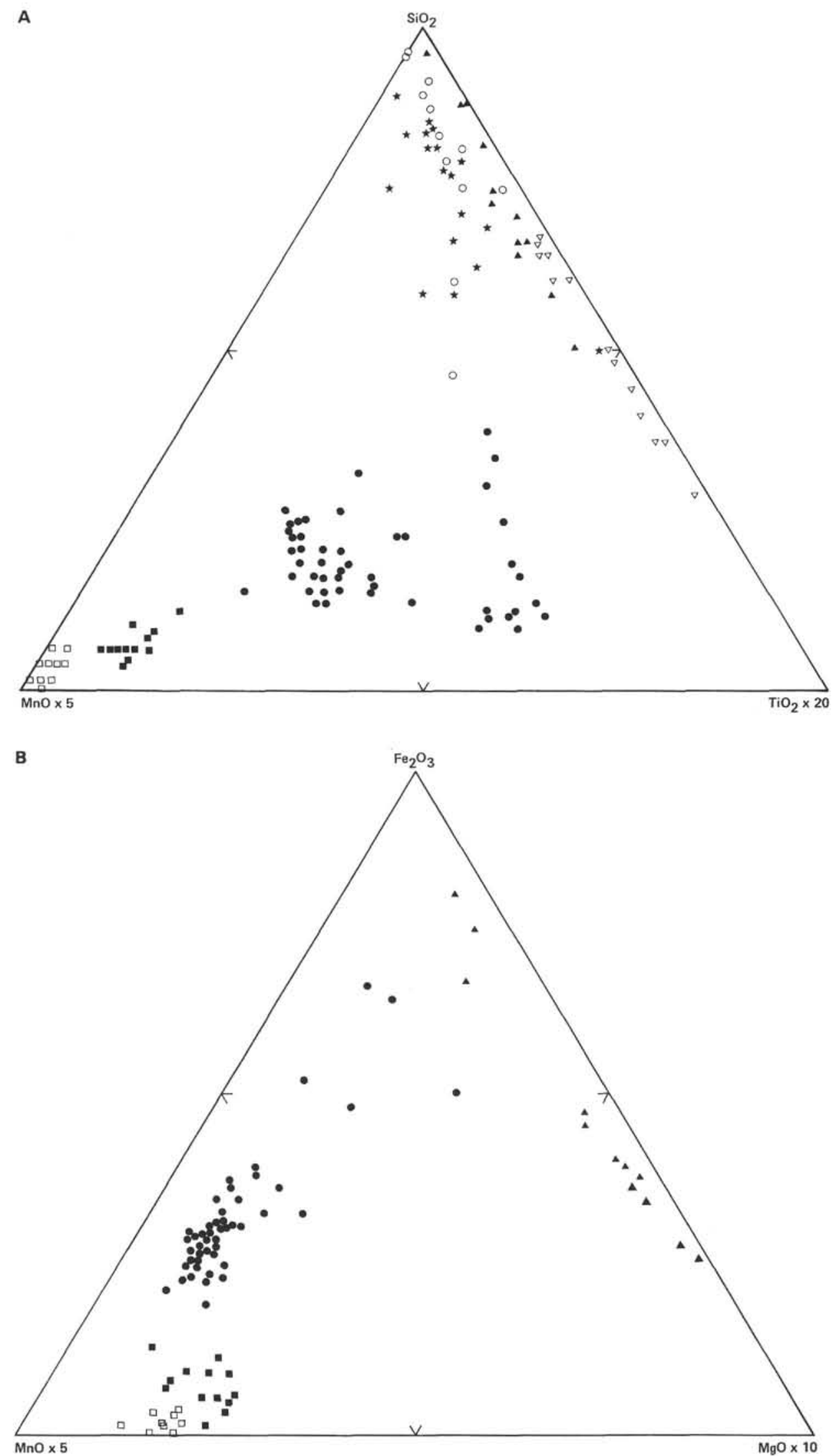

Figure 12. Ternary diagrams. A. Si-Ti-Mn projection. B. Fe-Mn-Mg projection. C. Fe-Al-Mg projection. (Same symbols as for Fig. 11.) Note: Multiplication factors have been applied to each pole to increase the discriminating power. 




Figure 12. (Continued).

The Mn-containing sediments can be differentiated from the Mn-less clays by the replacement of the $\mathrm{Si}-\mathrm{Mg}$ and $\mathrm{Mn}-\mathrm{Fe}$ affinities by a $\mathrm{Si}-\mathrm{Mg}$ exclusion in the latter and an $\mathrm{Mn}-\mathrm{Mg}$ affinity in the former. Except for the Tirich botryoid family, an $\mathrm{Fe}-\mathrm{Mg}$ exclusion appears in every class of sediment. The total correlation graph of the Mn oxides stresses the opposition between the Mn phase and a set of cations sharing strong positive correlations $(\mathrm{Si}$, $\mathrm{Al}, \mathrm{Fe}, \mathrm{Ca}, \mathrm{Na}$, and $\mathrm{Ti}$ ) susceptible to enter a diagenetic silicate frame excluding $\mathrm{K}$, which incidentally accompanies Mn. Such two-phase competition does not appear so clearly in the graphs of the two botryoid subfamilies because, in addition to $\mathrm{Mg}$ sharing links with both phases, Mn correlates positively with $\mathrm{Ti}$ and $\mathrm{Ca}$. The more silicate-related cations ( $\mathrm{Al}, \mathrm{Na}$, and $\mathrm{K}$ ) and $\mathrm{Fe}$ permit detection (by the similarity of their non-Mn concerned partial correlation subgraphs) of similitudes between the core of the first nodule and its Ti-rich botryoids on one side and its Mn-rich, Ti-poor botryoids and the second nodule's cortex on the other.

\section{Comments}

The different classes of sediment can be sorted following two successive geochemical trends. An aluminosilicate phase of various nature (lithogen and precipitation deposits) is challenged by a metalliferous precipitation consisting first of $\mathrm{Fe}$, second of $\mathrm{Mn}-\mathrm{Mg}$. The $\mathrm{Mn}$ gain, opposing the $\mathrm{Fe}$ gain, is closely linked with the $\mathrm{Mg}$ enrichment, and, like the botryoids, the Mn-richer fractions (Mn oxides of botryoidal laminations and grains in the cracks of the Site $552 \mathrm{Mn}$ nodule) show a common $\mathrm{Mn}-\mathrm{Mg}$ content increase that culminates in the $\mathrm{Mn}$ oxide grains along with an $\mathrm{Fe}$ content decrease. In the phyllite $\mathrm{Mn}$-less sediments, a common $\mathrm{Fe}-\mathrm{Mg}$ gain leads first to the white clays infilling the cracks of the Site 552 $\mathrm{Mn}$ nodule and next, a higher $\mathrm{Fe}$ gain, to the green clay facies encountered in both nodules.

\section{DISCUSSION}

In the three holes, drilling recovered a condensed sequence representing the middle Eocene to the middle Miocene with several unconformities sometimes marked by polymetallic concretions. The relationship between condensed sequences and nodules has already been recorded (Leclaire et al., 1976). In the DSDP holes, Fe-Mn concretions are not scarce; Glasby (1978) made a global review for the first 370 holes. Few Fe concretions were studied (Cronan, 1973; Aumento and MacGillivray, 1975). Sometimes the actual stratigraphic position determined by micropaleontological examination of the surface is not the same as for the sediment surrounding it (Cronan, 1973). It seems to be the case with the Hole 552 nodule (Backman, this volume) which would be formed before Zone NP20, like the Mn layer of Hole $554 \mathrm{~A}$. Bioturbation or sampling would raise it in the lithostratigraphic column.

The nodule from Hole 553 has a different origin than the Fe-Mn concretions from Holes 552 and 554. The botryoidal structure is the same but REE and transition element data (Table 3) are close to the nucleus of the 


\section{JEHANNO ET AL.}
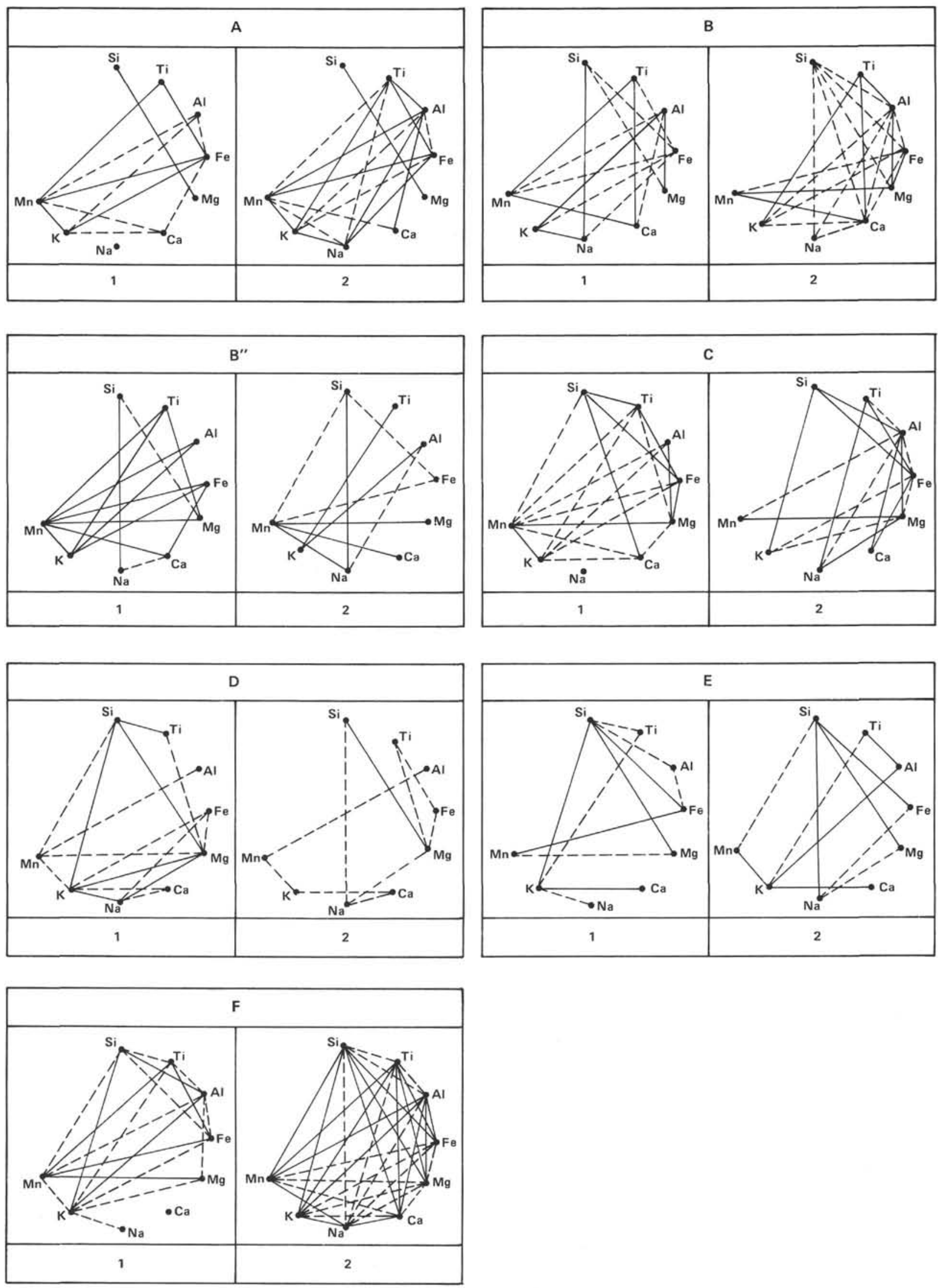

Figure 13. Total (1) and partial (2) correlation coefficient patterns representing the whole set of interelement affinities (continuous lines) and exclusions (dotted lines) in each of the morphological units. (Same symbols as for Fig. 11.) 
Hole 552 nodule and to the green clays. The brown clays from the Site 553 nodule and from the concretions found in the surrounding sediment are richer in $\mathrm{Fe}$ than the green clays and are often associated with goethite.

The Ce enrichment, often related to oxidizing conditions in the sedimentation medium (Ehrlich, 1968; Glasby, 1973; Michard and Renard, 1975; Renard, 1980), could occur not only with the Mn oxidation, but also with iron precipitation which has already been observed in weathering and palagonitization processes and in recent polymetallic nodules (Frey et al., 1974; BonnotCourtois, 1980; Courtois and Clauer, 1980; Bonnot-Courtois, 1981a,b). A comparison was made with Mn-poor concretions $\left(\mathrm{MnO}, 0.3 \% ; \mathrm{Fe}_{2} \mathrm{O}_{3}, 50.1 \%\right)$ covered by a Mn-rich encrustation ( $\mathrm{MnO}, 22 \% ; \mathrm{Fe}_{2} \mathrm{O}_{3}, 38 \%$ ) from Romancha deep in the Equatorial Atlantic Ocean (Bonté, 1981). Opposite the Hole 553 nodule, this sample has very high absolute REE concentrations (Table 3) with a strong positive $\mathrm{Ce}$ anomaly. Its X-ray pattern is that of poorly crystallized Fe-oxides (Fig. 5D), whereas the Xray pattern of the Hole 553 nodule shows only smectites (Fig. 3C).

The nucleus of Fe-Mn nodules is composed of any lithoclastic fragment or indurated sediment. So it is quite classical for the nucleus of the Hole 552 nodule to be formed by altered volcanogenic material. The ash layers are well developed in the three holes, especially during the middle-late Eocene period (see Site 552 chapter, this volume; Desprairies et al., this volume).

The Hole 552 nodule has the same morphological, mineralogical, and geochemical characteristics as recent "Atlantic" nodules (Cronan, 1981; Bonté, 1981). X-ray pattern comparison with a recent nodule from Bermuda $\left(27^{\circ} 05 \mathrm{~N}, 67^{\circ} 44 \mathrm{~W}\right.$, TRANSAT Cruise 1975 ; R.V. Le Noroit) shows that the mineralogy of the Hole 552 cortex was well preserved (Fig. 5). However, late crystallizations of zeolites and Mn phases in the cracks and in the external parts are well developed and imply a partial dislocation of the nodule followed by fillings. These crystallizations would be diagenetic features opposite to the hydrogenous character of the crust. They could take place from the beginning of the carbonated sedimentation; the Mn could be remobilized and then participate in the recrystallizations. The Mn-rich layers exist in the cortex of recent nodules with important fluctuations in their transition element concentrations (Sorem and Fewkes, 1979). The positive Ce anomaly occurring in the Hole 552 cortex $\left(\mathrm{Ce} / \mathrm{Ce}^{*}=7\right)$ is higher than the average value obtained in recent nodules $\left(\mathrm{Ce} / \mathrm{Ce}^{*} \simeq 3\right.$ ) (Ehrlich 1968; Piper, 1974a,b). A paleonodule from the Indian Ocean, interbedded in Cretaceous carbonate sediments and studied by one of us (Bonnot-Courtois, 1981a,b), presents the greatest positive $\mathrm{Ce}$ anomaly $\left(\mathrm{Ce} / \mathrm{Ce}^{*}=\right.$ $15)$. These observations set the problem of the variation of $\mathrm{Ce}$ anomalies in nodules during their aging.

Mn micronodules, with concentric structures, have the same mineralogical and geochemical compositions as micronodules occurring in superficial deep-sea sediments (Lallier-Verges and Clinard, 1983). Their $\mathrm{Mn} / \mathrm{Fe}$ ratios can reach a high value of 15 , and they are en- riched in transition elements. The "psilomelane" found at the top of the Hole 552 nodule emphasizes oxidizing conditions which permit the incorporation of great quantities of $\mathrm{Ba}$ in the $\mathrm{Mn}$-oxide structure. On the contrary, the second types of micronodules have a massive structure, with fibrous well-crystallized Mn oxides, similar to Mn-hydrothermal mineralizations from Galapagos mounds (Lalou et al., 1983), which are $\mathrm{Cu}, \mathrm{Co}$, and $\mathrm{Ni}$ poor. Their association with green clays similar to nontronites suggests that a local hydrothermal event could have occurred in this area after the opening of the rift between Greenland and Rockall during the Eocene. Nevertheless, this hypothesis needs more investigation, in particular concerning trace elements, because the Mndepleted green clays of the Hole 553 nodule also have a major element composition very close to that of nontronites from the Galapagos (McMurtry et al., 1983; Moorby, 1983). But REE and transition elements are higher than the concentrations found in typical hydrothermal green deposits (Hoffert et al., 1980; Corliss et al., 1978; Bonnot-Courtois, 1981a,b).

\section{CONCLUSION}

The fossil polymetallic concretions from Leg 81 , located in condensed sedimentary sequences, are formed during periods of very low sedimentation rates, as are the recent nodules.

The nodule from Hole 552, mineralogically and geochemically similar to surface nodules, suggests that the processes of genesis are the same from the Eocene to the present period. The diagenesis favors the filling of the cracks by post-recrystallizations of Mn-oxides and zeolites, and clays.

The various polymetallic concretions of Hole 554 could have formed differently. The micronodules with thin concentric laminations are typical of slow growth at the water/sediment interface or at the top of the sedimentary column. The massive micronodules, with flat crystals, could correspond to a faster growing Mn oxide, perhaps related to hydrothermal activity.

The Mn-less nodule from Site 553 is not a typical nodule with Mn depleted by leaching, but a clay concretion which was invaded by Fe hydroxides in the sedimentary column.

\section{REFERENCES}

Aumento, F., and MacGillivray, J. M., 1975. Geochemistry of buried Miocene-Pleistocene ferromanganese nodules from the Antarctic Ocean. In Hayes D. E., Frakes L. A., et al., Init. Repts. DSDP, 28: Washington (U.S. Govt. Printing Office), 795-803.

Bonnot-Courtois, C., 1980. Le comportement des terres rares au cours de l'altération sous-marine et ses conséquences. Chem. Geol., 30: 119-131.

, 1981a. Distribution des terres rares dans les dépôts hydrothermaux de la zone Famous et des Galapagos. Comparaison avec les sédiments métalliféres. Mar. Geol., 39:1-14.

1981b. Géochimie des terres rares dans les principaux milieux de formation et de sédimentation des argiles [Thése]. Université de Paris-Sud, Orsay.

Bonté, P., 1981. Relations entre l'environnement et les caractéristiques des concrétions polymétalliques marines dans la fosse de la Romanche [Thése]. Université de Paris-sud, Orsay. 
Brindley, G. W., and Brown, G., 1980. Crystal Structure of Clay Minerals and Their $X$-ray Identification: London (Mineralogical Society).

Corliss, J. B., Lyle, M., Dymond, J., and Crane, K., 1978. The chemistry of hydrothermal mounds near the Galapagos Rift. Earth Planet. Sci. Lett., 40:12-24.

Courtois, C., and Clauer, N., 1980. Rare earth elements and strontium isotopes of polymetallic nodules from Southeastern Pacific Ocean. Sedimentology, 27(6):687-695.

Courtois, C., and Jaffrezic-Renault, N., 1971. Utilisation des propriétés échangeuses d'ions du dioxyde d'étain pour l'analyse des lanthanides dans les roches par activation neutronique. C. R. Hebd. Seances Acad. Sci., 284 D:1139-1142.

Cronan, D. S., 1973. Manganese nodules in sediment cored during Leg 16, Deep Sea Drilling Project, In van Andel, T. H., Heath, G. R., et al., Init. Repts. DSDP, 16: Washington (U.S. Govt. Printing Office), 605-608.

1975. Manganese nodules and other ferromanganese oxide deposits from the Atlantic Ocean, J. Geophys. Res., 80:3831-3837.

Cronan, D.S., and Tooms, J. S., 1969. The geochemistry of manganese nodules and associated pelagic deposits from the Pacific and Indian Oceans. Deep-Sea Res., 16:335-359.

Desprairies, A., 1983. Relation entre le paramétre b des smectites et leur contenu en fer et magnésium. Application à l'étude des sédiments. Clay Miner.

Donn, W. L., and Ninkovitch, 1980. Rate of Cenozoic explosive volcanism in the North Atlantic Ocean inferred from deep sea cores, J. Geophys. Res., 85:5455-5460.

Ehrlich, A. Y., 1968. Rare earth abundances in manganese nodules, [Ph.D. Thesis]. Massachussetts Institute of Technology, Cambridge, Mass.

Frey, F. A., and Haskin, L. A., 1964. Rare earths in oceanic basalts. $J$. Geophys. Res., 69:775-780.

Frey, F. A., Bryan, W. B., and Thompson, G., 1974. Atlantic Ocean floor: geochemistry and petrology of basalts from Legs 2 and 3 of the Deep Sea Drilling Project. J. Geophys. Res., 79:5507-5527.

Gast, P. W., 1968. Trace element fractionation and the origin of tholeiitic and alkaline magma types. Geochim. Cosmochim. Acta, 32: 1057-1086.

Glassby, G. P., 1973. Mechanisms of enrichment of the rare elements in marine manganese nodules. Mar. Chem., 1:105-125.

1978. Deep-sea manganese nodules in the stratigraphic record: Evidence from D.S.D.P. Cores. Mar. Geol., 28:51-64.

Grousset, F., Joron, J. L., and Treuil, M., 1982. Identifications des sources des sédiments quaternaires de la dorsale médio-atlantique (Islande-Açores) à l'aide de la Géochimie des éléments de transition et des éléments hygromagmaphiles. Bull. Inst. Geol. Bass in Aquitaine, 31:239-256.

Hoffert, M., Person, A., Courtois, C., Karpoff, A. M., and Trauth, D., 1980. Sedimentology, mineralogy and geochemistry of hydrothermal and sedimentary deposits from Holes 424, 424A, 424B, 424C (Galapagos Spreading centre). In Rosendahl, B. R., Hekinian, R., et al., Init. Repts. DSDP, 54: Washington (U.S. Govt. Printing Office), 339-376.

Joron, J. L., Bougault, H., Wood, D. A., and Treuil, M., 1978. Application de la géochimie des éléments en traces à l'étude des propriétés et des processus de genèse de la croûte océanique et du manteau supérieur. Bull. Soc. Geol. Fr., XX(7): 521-531.

Joron, J. L., and Treuil, M., 1977. Utilisation des propriétés des éléments fortement hygromagmatophiles pour l'étude de la composition chimique et de l'hétérogénéité du manteau. Bull. Soc. Geol. Fr., XIX(7):1197-1205.

Juteau, T., Noack, Y., Whitechurch, H., and Courtois, C., 1980. Mineralogy and chemistry of alteration products in holes 417A and 417D basement samples (D.S.D.P. Leg 51). In Donnelly T., Francheteau J., Bryan, W., Robinson, P., Flower, M., Salisbury, M., et al., Init. Repts. DSDP, 51, 52, 53, Pt. 2: Washington (U.S. Govt. Printing Office), 1273-1297.

Ku, T. L., and Broecker, W. S., 1969. Radiochemical studies of Mn nodules of deep sea origin. Deep-Sea Res., 16:625-637.

Lallier-Verges, E., and Clinard, C., 1983. Ultra-thin section study of the mineralogy and geochemistry of Mn nodules from the South Pacific. Mar. Geol., 52:267-280.

Lalou, C., Brichet, E., Jehanno, C., and Perez-Leclaire, H., 1983. Hydrothermal manganese oxide deposits from Galapagos mounds D.S.D.P. Leg 70, hole 509B and "Alvin" dives 729 and 721. Earth Planet. Sci. Lett., 63:63-75.

Lebart, L., Mouneau, A., and Tabart, M., 1977. Techniques de la Description Statistique. (Paris) (Dunod Ed.).

Leclaire, L., Clocchiatti, M., Müller, C., Caulet, J. P., and Giannesini, P. J., 1976. Lacunes de sédimentation, séries condensées et nodules de manganèse dans les dépôts néogènes et quaternaires des bassins de l'océan Indien Austral. Bull. Soc. Geol. Fr., XVIII, (7): $725-746$.

Ludden, J. N., and Thompson, G., 1978. Behaviour of rare earth elements during submarine weathering of tholeiitic basalt. Nature (London), 274:147-149.

1979. An evaluation of the behavior of the rare earth elements during the weathering of sea-floor basalt. Earth Planet, Sci. Lett., 43:85-92.

McMurtry, G. M., Wang, C. H., and Yeh, H. W., 1983. Chemical and isotopic investigations into the origin of clay minerals from the $\mathrm{Ga}-$ lapagos hydrothermal mounds field. Geochim. Cosmochim. Acta, 47:475-489.

Michard, G., and Renard, D., 1975. Possibilitiés d'entraînement du $\mathrm{Co}, \mathrm{Pb}$ et $\mathrm{Ce}$ dans les nodules de manganèse par oxydation. $C$. $R$. Hebd. Seances Acad. Sci., 280 D:1761-1764.

Moorby, J. A., 1983. The geochemistry of transitional sediments recovered from the Galapagos hydrothermal mounds field during D.S.D.P. Leg 70. Implications for mounds formations. Earth Planet, Sci. Lett., 62:367-376.

Piper, D. Z., 1974a. Rare earth elements in the sedimentary cycle: a summary Chem. Geol., 14:285-304. $1974 \mathrm{~b}$. Rare earth elements in ferromanganese nodules and other marine phases. Geochim. Cosmochim. Acta, 38:1007-1022.

Renard, D., 1980. Etude Géochimique de l'incorporation du manganèse et des éléments associés dans les nodules polymétalliques [Thése]. Université de Paris, Paris.

Rivière, A., 1969. Sur une meilleure estimation des corrélations linéaires partielles par l'emploi de coefficients de corrélations linéaires partiels orientés. C. R. Hebd. Seances Acad. Sci., 268 D: 763-766.

Sigurdsson, H., and Loebner, B., 1981. Deep sea record of cenozoic explosive volcanism in the North Atlantic. In Self, S., and Sparks, R. S. J. (Eds.), Tephra Studies: Dordrecht, Netherlands (Reidel Publishing Company), pp. 289-316.

Somayulu, B. L. K., Heath, G. R., Moore, T. C., and Cronan, D. S., 1971. Rates of accumulation of manganese nodules and associated sediment from the equatorial Pacific. Geochim. Cosmochim. Ac$t a, 35: 621-624$.

Sorem, R. K., and Fewkes, R. H., 1979. Manganeses Nodules. Research Data and Methods of Investigation: New York (IFI/Plenum Data Company).

Stonecipher, S. A., 1978. Chemistry of deep-sea phillipsites, clinoptilolite and host sediments. In Sand L. B., Mumpton F. A. (Eds.), Natural Zeolites, Occurrence, Properties, Uses (1st ed.): Oxford (Pergamon Press), pp. 221-234.

Weaver, C. E., and Pollard, L. D., 1973. The chemistry of clay minerals. Dev. Sedimentol., 15.

Date of Acceptance: September 30, 1983 


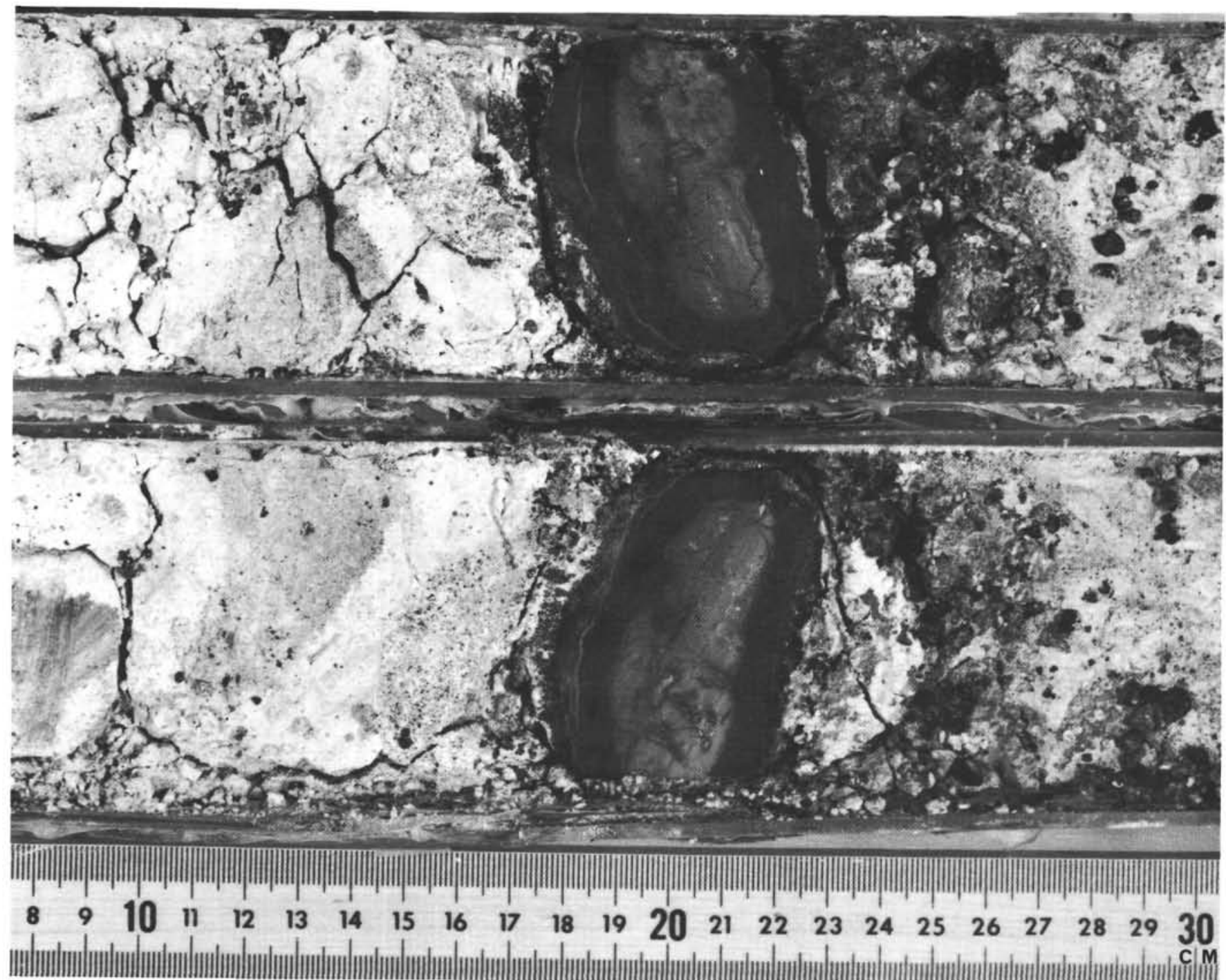

Plate 1. Nodule in core section from Hole 552A. 

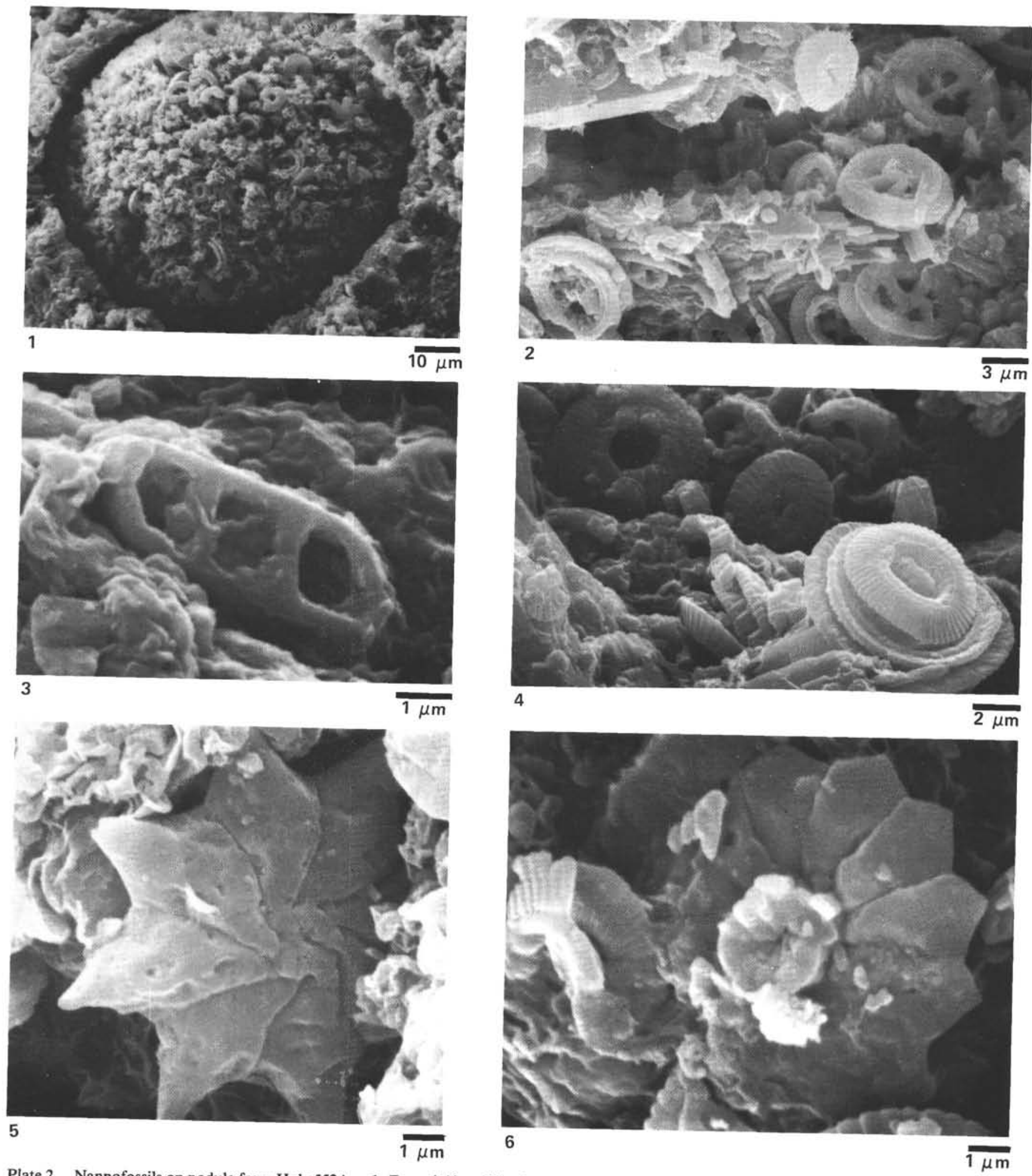

Plate 2. Nannofossils on nodule from Hole 552A. 1. Foraminifers filling in outer part. 2. Chiasmolithus sp., clays and phillipsite. 3. Isthmolithus recurvus (Deflandre). 4. Reticulofenestra umbilica (Martini and Ritzkowski). 5. Discoaster saipanensis (Bramlette and Riedel). 6. Disco-
aster barbadiensis (Tan). 

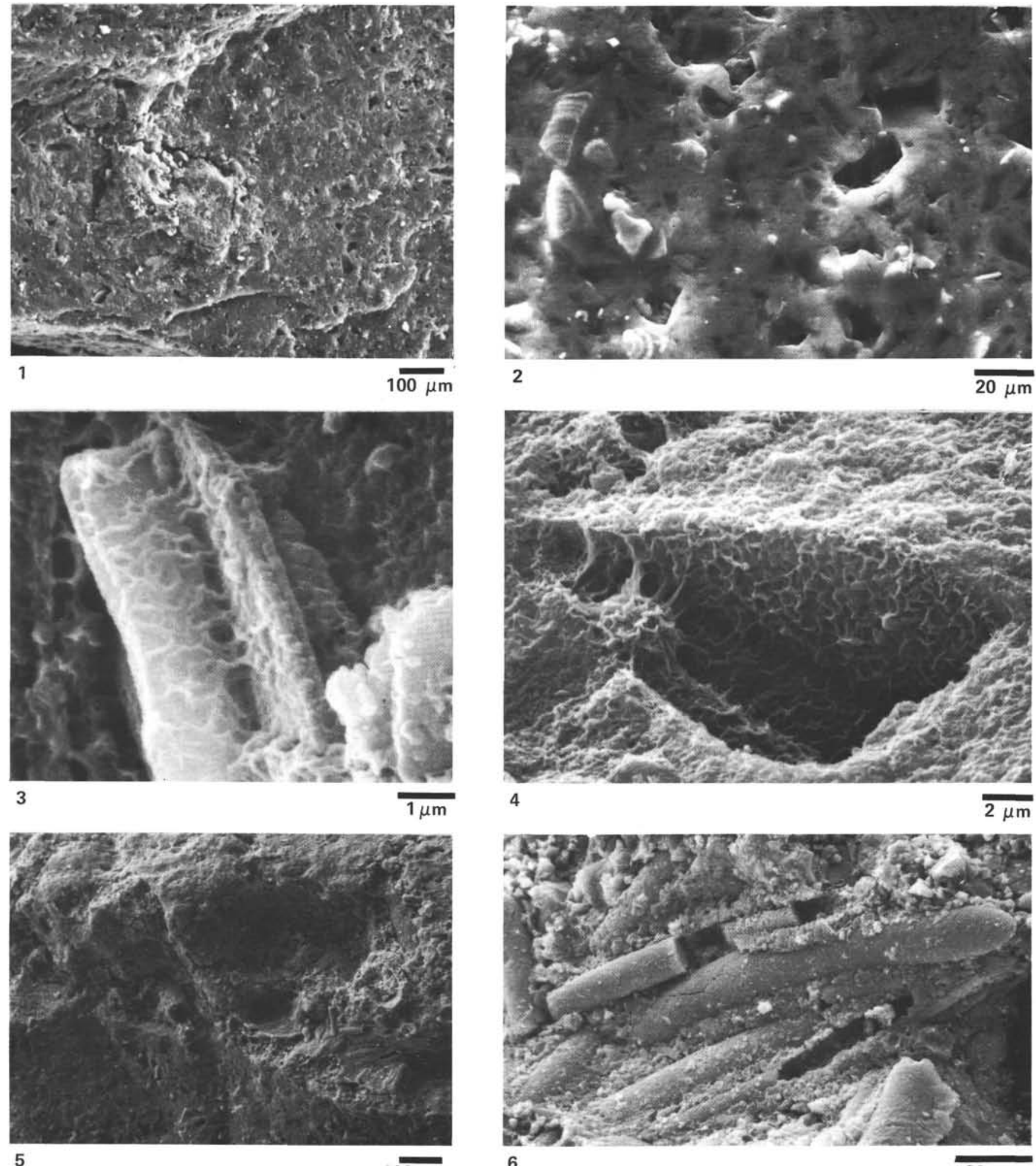

$100 \mu \mathrm{m}$



Plate 3. Nucleus of nodule from Hole 552A. 1. Fragment with volcanic glass cavities. 2. Polished section near crack with cavities and onionlike Mn structures (on left). 3. Residual mineral covered with clays. 4. Clay on cavity walls. 5. Nucleus-crust contact. Upward: nucleus, biogenic remnants, crust. 6. Biogenic remnants. 

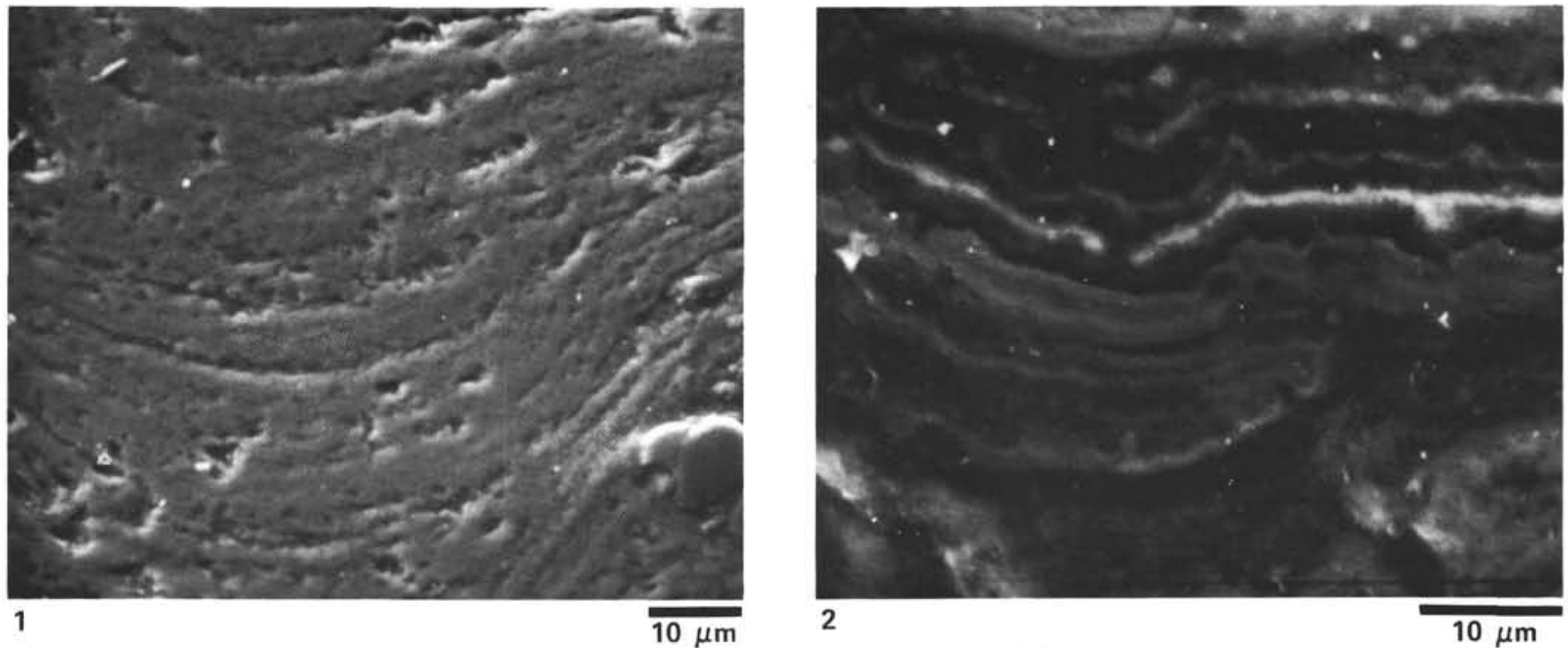

1
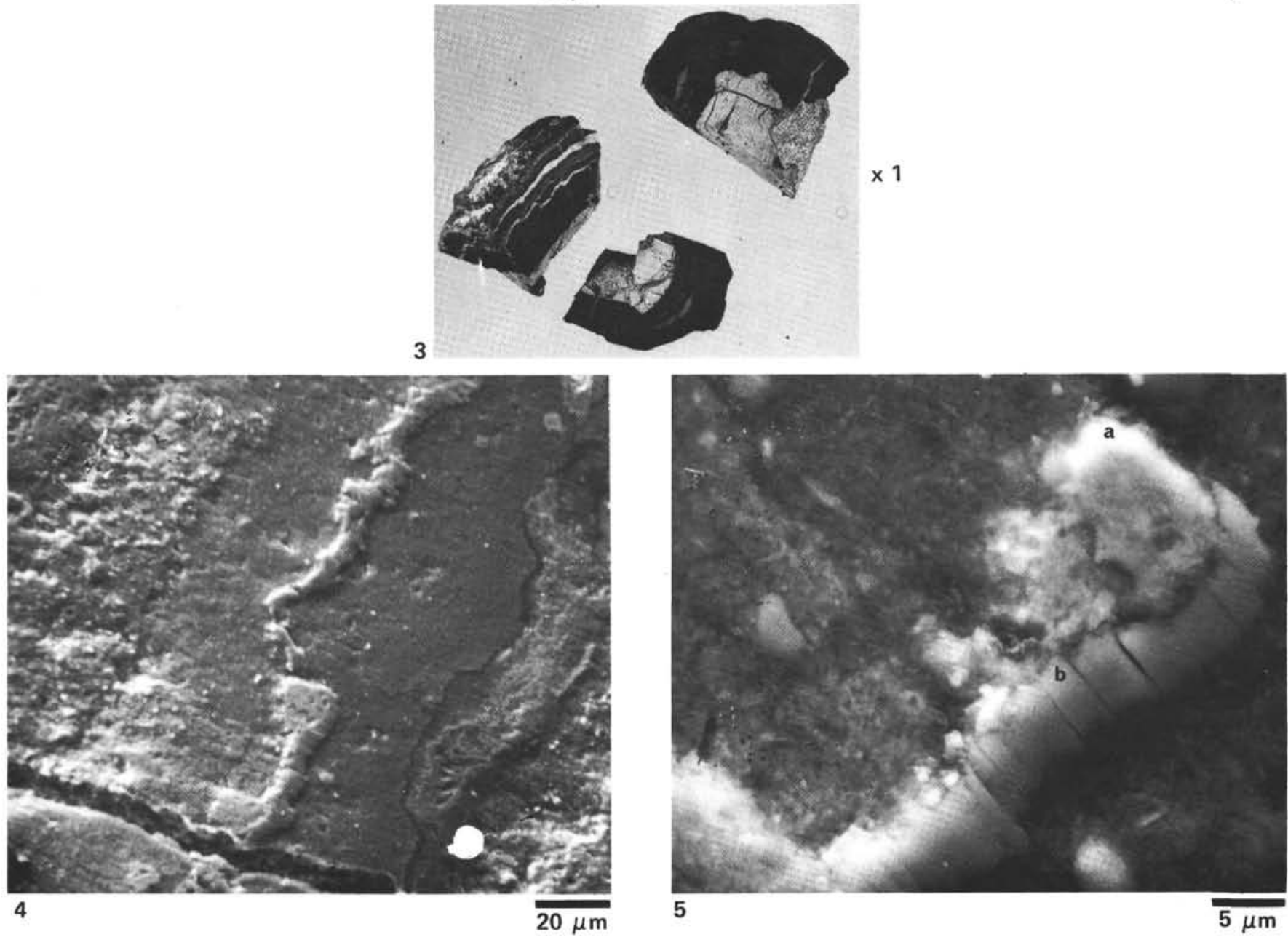

Plate 4. Crustal zone of nodule from Hole 552A. 1. $\delta \mathrm{MnO}_{2}$ botryoid. 2. Thin layers or todorokite (white). 3. Fragments (on left): upper part with cracks. 4, 5. Radial crack with Mn oxides (a) and phillipsite (b). 

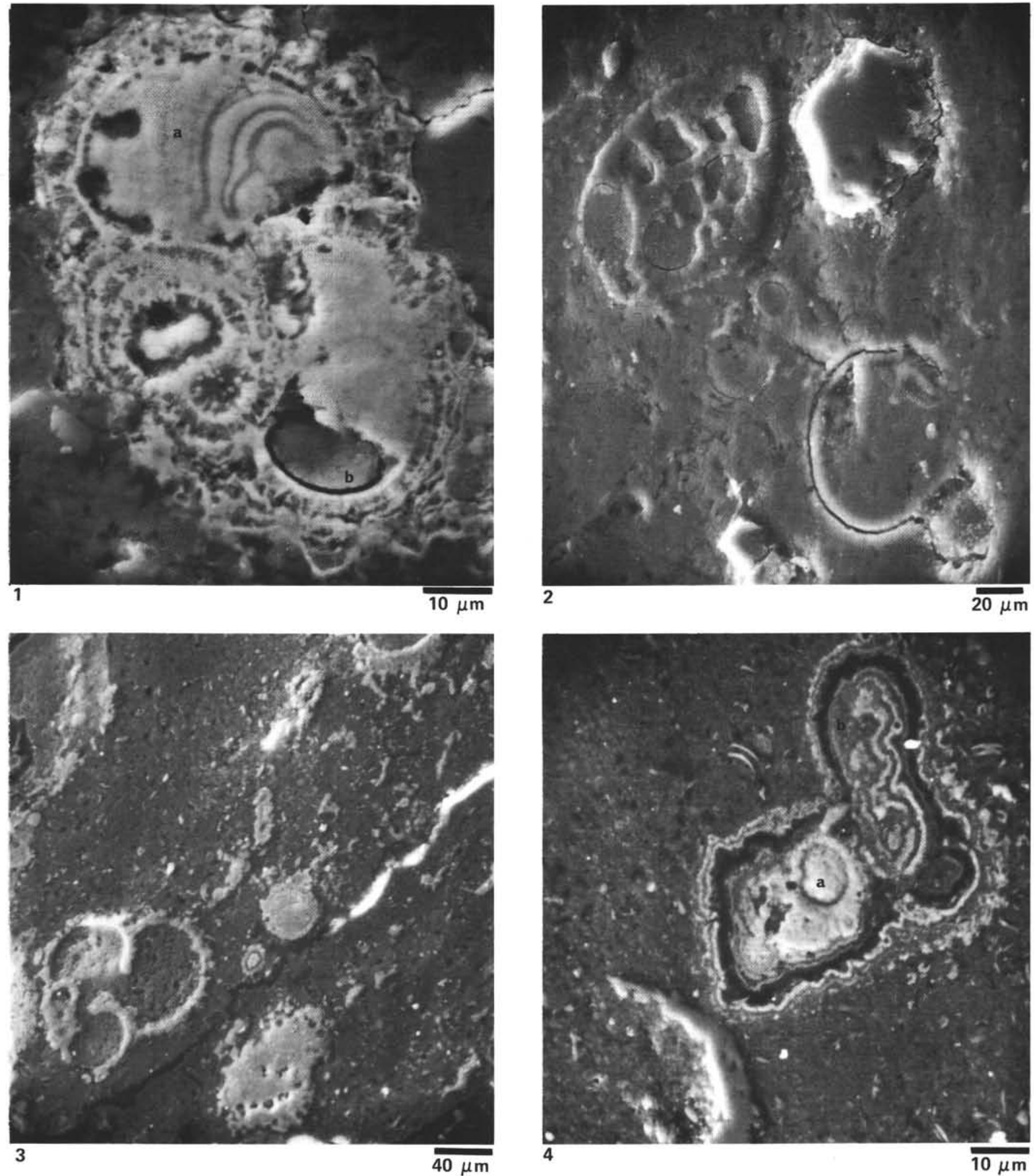

Plate 5. Nodule from Hole 552A. Clays and Mn oxides in cracks. 1. External foraminifer filled with (a) psilomelane, (b) green clay. 2. Green clay with quartz and foraminifer test, in concentric crack. 3,4 . White clay with foraminifers and coccoliths, phillipsite and micronodule (a $=$ todorokite; $\mathrm{b}=\delta \mathrm{MnO}_{2}$ ). 

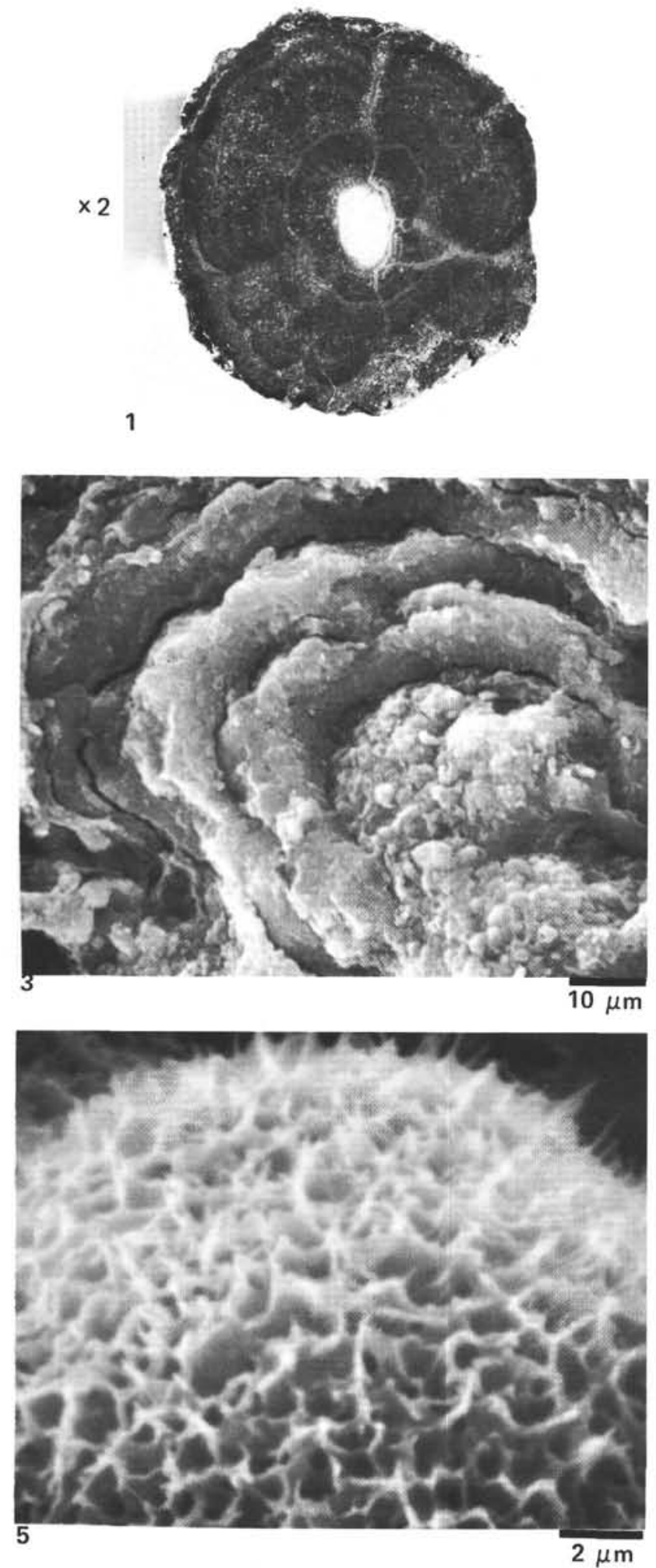
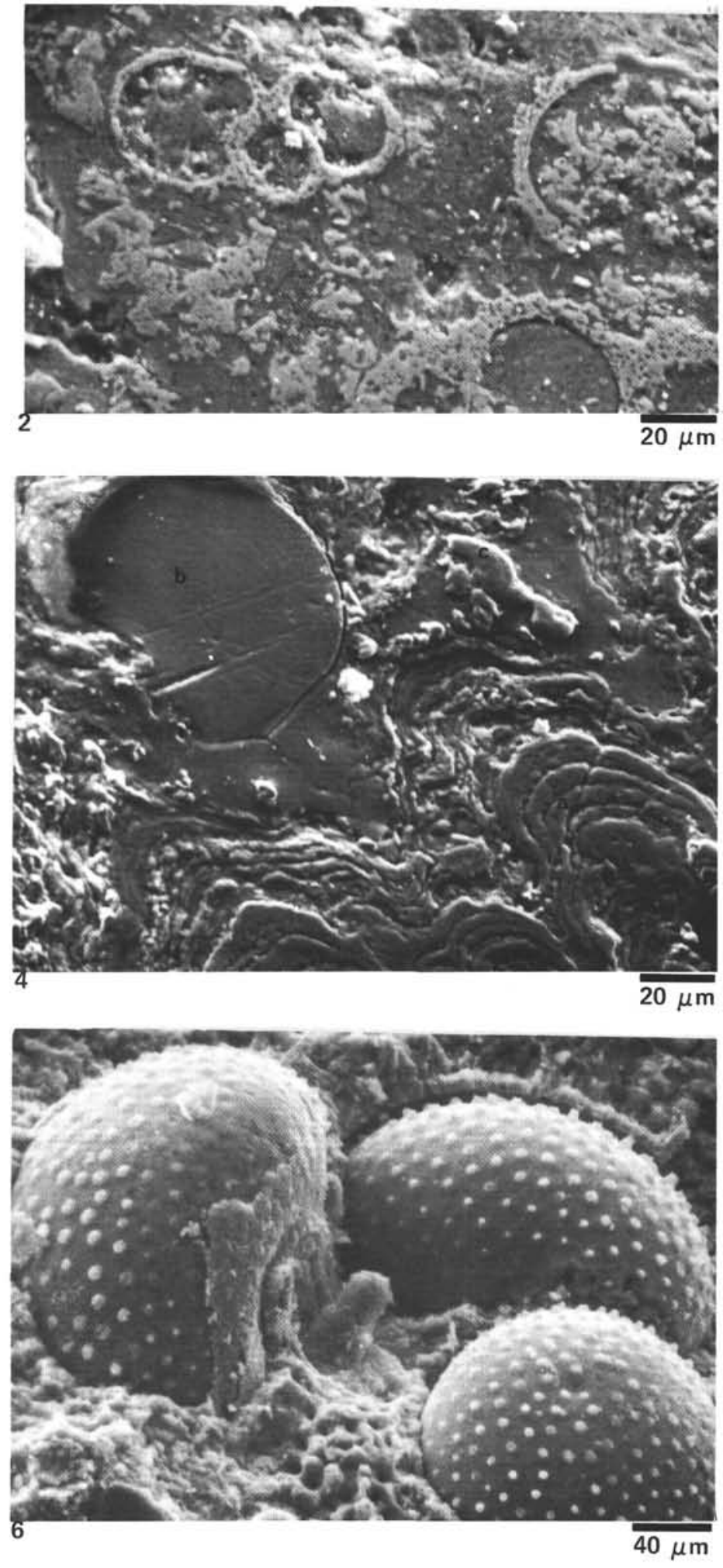

Plate 6. Nodule from Hole 553A. 1. Polished section. 2. Phillipsite in place of carbonate in green clays of the nucleus. 3. Botryoid of brown clay. 4. Crustal zone polished section, (a) botryoid of brown clay, (b) green clay filling, (c) phillipsite. 5. Smectites at the outer part. $\mathbf{6}$. Clay filling of foraminifer in surrounding sediment. 

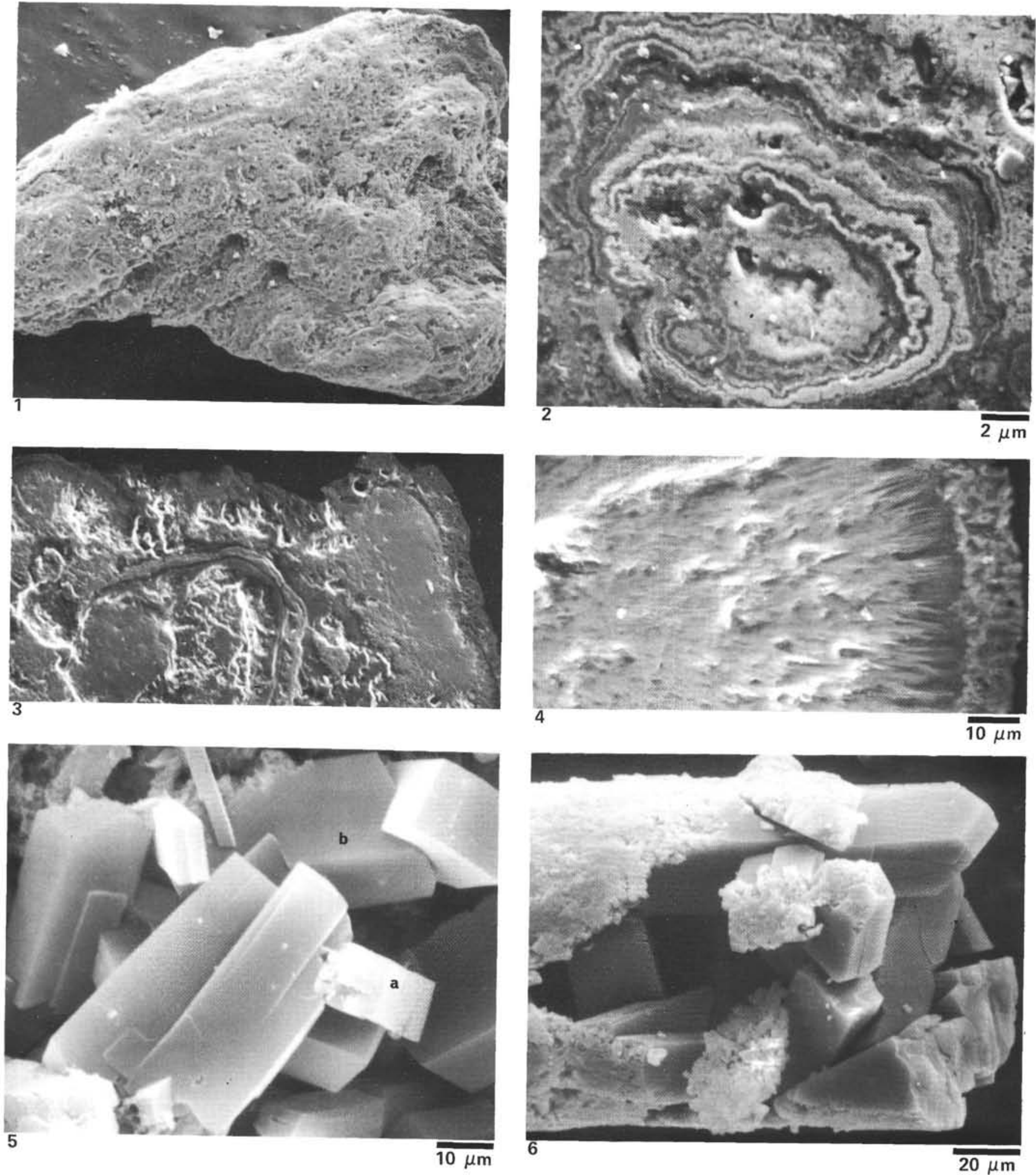

Plate 7. Concretions from Hole 554A. 1. $\delta \mathrm{MnO}_{2}$ fragment, $\times 40$. 2. Onionlike structure of micronodule. 3, 4. Mn-rich deposit with fibrous texture, $\times 80$. 5. Zeolites in sediment, (a) phillipsite, (b) clinoptilolite. 6. Phillipsite filling in biogenic remnant. 